\title{
Evaluation dam overtopping risk based on univariate and bivariate flood frequency analysis
}

Evaluation dam overtopping risk

E. Goodarzi et al.

\section{E. Goodarzi, M. Mirzaei, L. T. Shui, and M. Ziaei}

Department of Biological and Agricultural Engineering, Faculty of Engineering, University Putra Malaysia, Malaysia

Received: 3 October 2011 - Accepted: 20 October 2011 - Published: 8 November 2011 Correspondence to: E. Goodarzi (ehsan.g@ hotmail.com)

Published by Copernicus Publications on behalf of the European Geosciences Union.

Title Page

Abstract

Introduction

Conclusions

References

Tables

Figures

14 $\rightarrow 1$

4

Back

Close

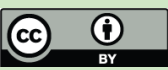




\section{Abstract}

There is a growing tendency to assess the safety levels of existing dams based on risk and uncertainty analysis using mathematical and statistical methods. This research presents the application of risk and uncertainty analysis to dam overtopping based on

5 univariate and bivariate flood frequency analyses by applying Gumbel logistic distribution for the Doroudzan earth-fill dam in south of Iran. The bivariate frequency analysis resulted in six inflow hydrographs with a joint return period of $100-y$ r. The overtopping risks were computed for all of those hydrographs considering quantile of flood peak discharge (in particular 100-yr), initial depth of water in the reservoir, and discharge (he water, as most important factor in the overtopping analysis, was evaluated using reservoir routing and the Monte Carlo and Latin hypercube techniques were applied for uncertainty analysis. Finally, the achieved results using both univariate and bivariate frequency analysis have been compared to show the significance of bivariate analyses on dam 15 overtopping.

\section{Introduction}

Special consideration should be given to all hydraulic structures such as dams or flood control embankments to prevent collapse of those structures. For instance, the proper design of a dam's spillway and the flood control capacity of a reservoir can ensure the safety of a dam and avoid any undesirable problems such as overtopping. Hence an exact estimate of flood design and extreme inflow hydrographs is required for the design of such important hydraulic structures. The design flood for a hydraulic structure can be defined as maximum flood flows that a structure can pass it safely. The common method to evaluate design flood is univariate frequency analysis of peak discharges. In other word, the frequency analysis of recorded peak discharges could be used to characterize the flood potential at desire site. Although, the univariate flood frequency
HESSD

8, 9757-9796, 2011

Evaluation dam overtopping risk

E. Goodarzi et al.

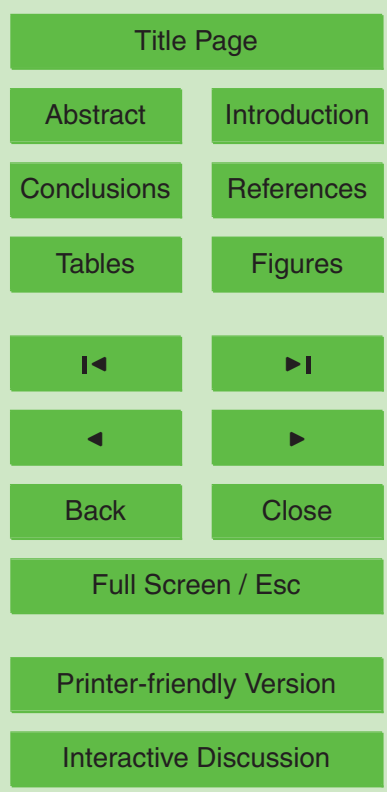

Interactive Discussion 
analysis still is using to evaluate peak discharges in desire return periods, it is not a highly accurate technique and cannot provide complete assessment of true probabilities of occurrence. While many hydrological problems require knowledge of complete information concerning a flood event, e.g. flood peak flow, flood volume, flood duration, 5 shape of the hydrograph, and etc. Floods inherently are multivariate random events and other hydrological variables such as inflow volumes and duration of hydrograph should be considered in frequency analysis.

Cunnane (1988), and Bobee and Rasmussen (1994) studied univariate flood frequency analysis comprehensively. Their results showed that univariate flood frequency 10 analysis does not provide an accurate assessment of flood condition and bivariate or multivariate frequency analyses which consider other parameters such as direct runoff volume and duration of hydrograph in conjunction with peak discharges should be applied to better characterize inflow hydrographs and reduce uncertainty in flood analysis. A number of attempts have been made to perform bivariate and multivariate flood fre15 quency analyses that take into consideration the dependence among flood variables e.g. flood peak, volume, and duration but with restrictive assumptions. Singh (1991) derived bivariate probability distributions with exponential marginal. Goel et al. (1998) analyzed a three-variate flood frequency after normalizing flood volume, peak discharge and duration of inflow hydrographs. Yue et al. (1999) used the Gumbel mixed distribution for both peak discharges and flood volume. Yue $(2001 \mathrm{a}, \mathrm{b})$ analyzed multivariate flood frequency using the bivariate extreme value distribution and bivariate lognormal distribution. De Michele et al. (2005) considered a bivariate probability distribution using the concept of 2-Copulas, and a bivariate extreme value distribution with generalized extreme value marginals is proposed in their study. Furthermore, the hydrological 25 safety of dams was considered to check the adequacy of dam spillway and the reservoir behavior was tested using a long synthetic series of flood hydrographs. Yanmaz and Gunindi (2008) assessed the overtopping reliability of a dam using the bivariate flood frequency analysis. Through their study, the maximum reservoir elevation and risk of overtopping had been determined by performing a probabilistic reservoir routing

\section{HESSD}

8, 9757-9796, 2011

\section{Evaluation dam overtopping risk}

E. Goodarzi et al.

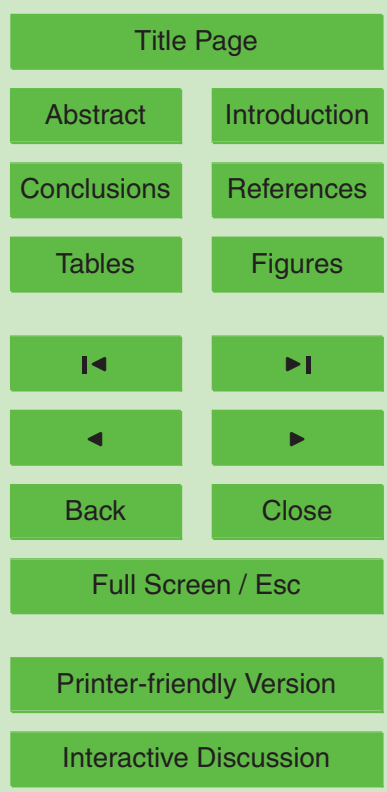

\section{9}


based on Monte Carlo simulation. The Other significant studies with regards to bivariate topic include; Raynal (1985), Raynal and Salas (1987), Correia (1987), Sackl and Bergmann (1987), Krstanovic and Singh (1987), Loganathan et al. (1987), Choulakian et al. (1990), Escalante and Dominguez (1997), Kelly and Krzysztofowicz (1997).

5 In this study, risks of overtopping in conjunction with uncertainty were estimated based on univariate and bivariate flood frequency analyses for an earth-fill dam. The main uncertain factors in the univariate frequency were quantile of flood peak discharge $\left(Q_{\mathrm{p}}\right)$, initial depth of water in the reservoir $\left(H_{0}\right)$, and the spillway discharge coefficient $(C)$, and in the bivariate analysis were; initial depth of water in the reservoir $\left(H_{0}\right)$, and 10 the spillway discharge coefficient $(C)$.

\section{Bivariate frequency analysis}

As is stated, design flood are not only described by peak discharge values, but also it is a function of other factors such as direct runoff volume and duration of flood. Based on Yue and Rasmussen (2002), if a given hydrological event is multivariate, in 15 that case univariate frequency analysis cannot provide complete assessment of the probability of occurrence and a better understanding of the statistical characteristics of such events needs consideration of their joint distribution. In particular, when the capacity of reservoir is large the volume of flood has an important effect on dam safety and overflowing event. Hence a bivariate flood frequency using the Gumbel logistic distribution was applied to demonstrate joint distribution of peak discharges and direct volume of runoff. The bivariate Gumbel logistic distribution can be written as follow:

$F_{Q, V}\left(Q_{\mathrm{p}}, V\right)=\exp \left\{-\left[\left(-L n F_{Q_{p}}\left(Q_{\mathrm{p}}\right)\right)^{m_{\mathrm{r}}}+\left(-L n F_{V}(V)\right)^{m_{\mathrm{r}}}\right]^{1 / m_{\mathrm{r}}}\right\}, m_{\mathrm{r}}>1$

where $m_{r}\left(m_{r} \geq 1\right)$ is the parameter describing the association between two random variables $Q_{\mathrm{p}}$ and $V$. The estimator of $m_{\mathrm{r}}$ is given by (Gumbel and Mustafi, 1967;

HESSD

8, 9757-9796, 2011

\section{Evaluation dam overtopping risk}

E. Goodarzi et al.

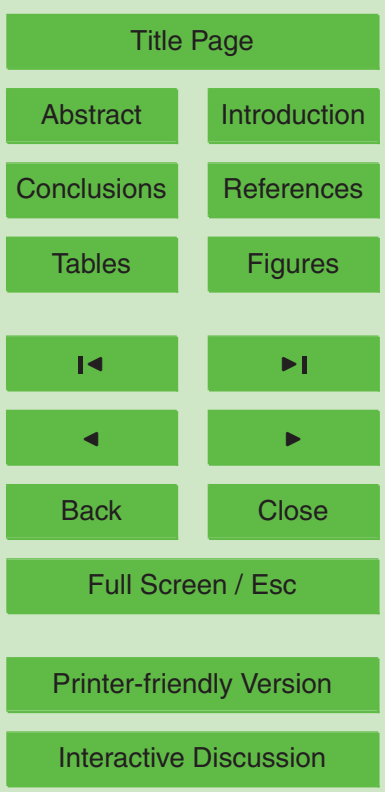

Interactive Discussion 
Johnson and Kotz, 1972):

$m_{\mathrm{r}}=\frac{1}{\sqrt{1-p}}$

HESSD

and

$\rho=\frac{E\left[\left(Q_{\mathrm{p}}-\mu_{Q_{\mathrm{p}}}\right)\left(V-\mu_{V}\right)\right]}{\sigma_{Q_{\mathrm{p}}} \sigma_{V}}$

5 Where $\rho$ is the correlation coefficient between two variables, and $\mu$ and $\sigma$ are the mean and standard deviation indicators, respectively (Singh et al., 2005). The marginal distribution of $F_{Q_{p}}(Q)$ and $F_{V}(V)$ are presented through the Eqs. (3) and (4) as;

$F_{Q_{p}}(Q)=\exp \left\{-\exp \left(-\frac{Q_{p}-\beta}{\alpha}\right)\right\}$

and

${ }_{10} \quad F_{V}(V)=\exp \left\{-\exp \left(-\frac{V-\beta}{\alpha}\right)\right\}$

In which, $\alpha$ and $\beta$ are:

$\alpha=\sqrt{6}\left(\frac{\sigma}{\pi}\right)$

and

$\beta=\mu-0.577 \alpha$

15 where $\mu$ and $\sigma$ are the mean and standard deviation of recorded data, respectively (Singh et al., 2005). The joint PDF can be derived using Eq. (1) as follows;

$f\left(Q_{\mathrm{p}}, V\right)=\frac{\partial^{2} F\left(Q_{\mathrm{p}}, V\right)}{\sigma_{Q_{\mathrm{p}}} \sigma_{V}}=\frac{F\left(Q_{\mathrm{p}}, V\right)}{\sigma_{Q_{\mathrm{p}}} \sigma_{V}}\left[e^{-m_{\mathrm{r}} \frac{Q_{\mathrm{p}}-\mu_{Q_{\mathrm{p}}}}{\sigma_{Q_{\mathrm{p}}}}}+e^{-m_{\mathrm{r}} \frac{V-\mu_{V}}{\sigma_{V}}}\right]^{\frac{1-2 m_{\mathrm{r}}}{m_{\mathrm{r}}}}$

Evaluation dam overtopping risk

E. Goodarzi et al.

Title Page

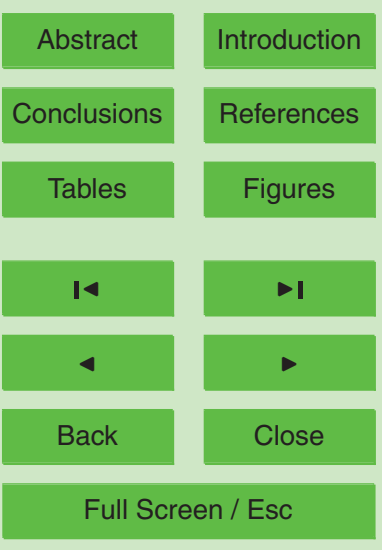

Printer-friendly Version

Interactive Discussion

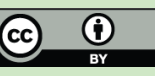


$\times\left(\left[e^{-m_{\mathrm{r}} \frac{Q_{\mathrm{p}}-\mu_{Q_{\mathrm{p}}}}{\sigma_{Q_{\mathrm{p}}}}}+e^{-m_{\mathrm{r}} \frac{V-\mu_{V}}{\sigma_{V}}}\right]^{\frac{1}{m_{\mathrm{r}}}}+m_{\mathrm{r}}-1\right) \times\left[e^{-m_{\mathrm{r}}\left(\frac{Q_{\mathrm{p}}-\mu_{Q_{\mathrm{p}}}}{{ }^{\sigma} Q_{\mathrm{p}}}+\frac{V-\mu_{V}}{\sigma_{V}}\right)}\right]$

HESSD

According to Yue (2001) and Salvadori and De Michele (2004), there are several kind of bivariate return periods including OR, AND, conditional, and secondary. The return period associated with single event $Q_{\mathrm{p}}>q_{\mathrm{p}}$ or $V>v$ can be written as;

$\left\{\begin{aligned} T\left(Q_{p}\right)= & \frac{1}{1-F_{Q_{p}}\left(Q_{p}\right)} \\ T(V)= & \frac{1}{1-F_{V}(V)}\end{aligned}\right.$

On the basis of the same principle, the joint return period $T\left(Q_{\mathrm{p}}, V\right)$ of $Q_{\mathrm{p}}$ and $V$ associated with the event that either " $Q_{\mathrm{p}}$ " OR " $V$ " OR both are exceeded $\left(Q_{\mathrm{p}}>q_{\mathrm{p}}, V>v\right.$, OR $Q_{\mathrm{p}}>q_{\mathrm{p}}$ and $V>v$ ) can be represented by:

$T\left(Q_{\mathrm{p}}, V\right)=\frac{1}{1-F_{Q_{\mathrm{p}}, V}\left(Q_{\mathrm{p}}, V\right)}$

10 Similarly, the joint return period $T\left(Q_{\mathrm{p}}, V\right)$ of $Q_{\mathrm{p}}$ and $V$ associated with the event that both " $Q_{p}$ " AND " $V$ " are exceeded $\left(Q_{p}>q_{p}\right.$ AND $\left.V>v\right)$ is (Yue, 2001):

$T\left(Q_{\mathrm{p}}, V\right)=\frac{1}{1-F_{Q_{\mathrm{p}}}\left(Q_{\mathrm{p}}\right)-F_{V}(V)+F_{Q_{\mathrm{p}}, V}\left(Q_{\mathrm{p}}, V\right)}$

The other kinds of conditional bivariate return period were presented by Yue (2001) and Salvadori and De Michele (2004). In this study, the OR type joint return period

15 (Eq. 10) were applied in bivariate flood frequency analysis and assumed if the peak discharge is too high OR its flood volume is too large, a dam can be at risk. More information about the above return period equations and their effect on flood frequency analysis were presented in Yue (2001).

Evaluation dam overtopping risk

E. Goodarzi et al.

Title Page

Abstract

Introduction

Conclusions

References

Tables

Figures

14

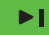

4

Back

Close

Full Screen / Esc

Printer-friendly Version

Interactive Discussion 


\section{Reservoir routing}

The main objective of the overtopping analysis of an earth-filled dam is estimating the height of water in the reservoir under various inflows and comparing the result with the elevation of dam crest. The known flood model that is frequently used is the continuity 5 equation. The basic form of this equation can be written as:

$Q_{\text {in }}-Q_{\text {out }}=\frac{\mathrm{d} S}{\mathrm{~d} t}$

where, $Q_{\text {in }}$ and $Q_{\text {out }}$ are inflow and outflow of the reservoir, respectively; $S$ is storage; and $t$ is time. The discrete form of the above equation can be written as:

$\frac{Q_{\mathrm{in}_{t}}+Q_{\mathrm{in}_{t+1}}}{2}-\frac{Q_{\text {out }_{t}}+Q_{\text {out }_{t+1}}}{2}=\frac{S_{t+1}-S_{t}}{\Delta t}$

10 Where, $Q_{\mathrm{in}_{t}}$ and $Q_{\mathrm{in}_{t+1}}$ are inflows to reservoir, $Q_{\text {out }_{t}}$ and $Q_{\text {out }_{t+1}}$ are outflows from the reservoir, $S_{t}$ and $S_{t+1}$ are storage in reservoir at $t$ and $t+1$, respectively and $\Delta t$ is time interval. The hydrograph of the water profile in the reservoir and the maximum height of water could be estimated by solving Eq. (13) step by step. The time interval $\Delta t$ determines the length of each step in the reservoir routing equation and precision

15 of output will be increased by decreasing $\Delta t$. In this study a time interval of one hour was selected to increase the accuracy of results and consequently decreasing the uncertainty of $\Delta t$. Furthermore, the fourth order Runge-Kutta was applied to solve the reservoir routing.

\section{Risk model}

20 The failing of a system occurs when the system is unable to perform the expectations and undesirable consequences occur. The failure can be defined as the load $(L)$ exceeding the resistance or capacity $(R)$ of the system. Tung et al. (2005) defined the

HESSD

8, 9757-9796, 2011

\section{Evaluation dam} overtopping risk

E. Goodarzi et al.

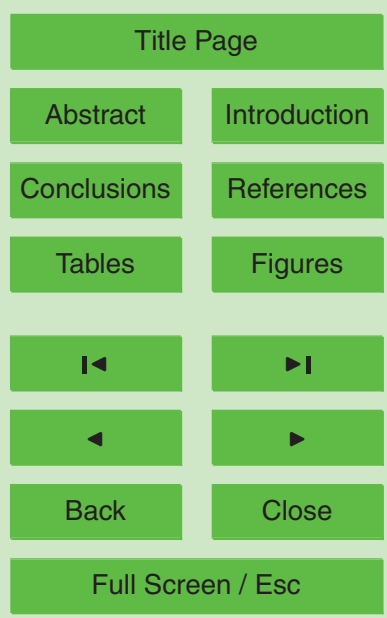

Printer-friendly Version

Interactive Discussion 
probability of failure as;

Probability of failure $=P(L>R)$

HESSD

Where $P([]$.$) is the probability of the desired event.$

The identification of the load and resistance is fundamental in risk analysis and highly 5 depends on the type of hydraulic structure and the physics of the problem. In the overtopping analysis, the height of water in the reservoir $\left(H_{\max }\right)$ and the height of dam $H_{\mathrm{R}}$ can be considered as load and resistance of system, respectively. In the risk and reliability analysis Eq. (14) can be written in the form of performance function $(Z)$ as follows:

$10 \quad Z=\ln \left(\frac{R}{L}\right)=\ln \left(\frac{H_{\mathrm{R}}}{H_{\max }}\right)$

Generally, the performance function of an engineering system can be described in several forms in which the selection of each form depends on the distribution type of the performance function. More information about the various forms of performance function and their applications to hydraulic engineering systems are presented by Yen (1979). Based on Eq. (15), risk can be calculates as:

$\alpha=$ Risk $=P(Z<0)$

Another important factor is reliability index which is shown by $\beta$ and it frequently uses in the risk analysis and uncertainty. This factor is defined as the ratio of the mean of performance function to its standard deviation and so it could be written as;

${ }_{20} \beta=\frac{\mu_{Z}}{\sigma_{Z}}$

By assuming normal distribution for $Z$ (Kuo et al., 2007) the risk can be computed as follow;

Risk $=1-\varnothing(\beta)$

where $\varnothing($.$) is the cumulative normal standard probability corresponding to \beta$.

Evaluation dam overtopping risk

E. Goodarzi et al.

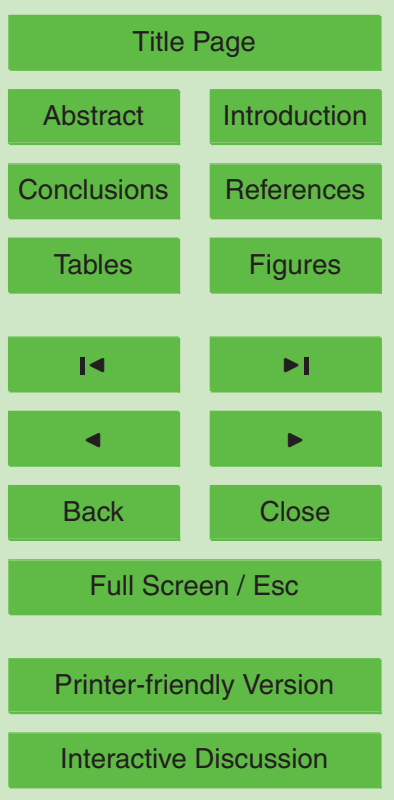




\section{Uncertainty analysis}

In water resource engineering, making a decision about the operation and capacity of the system is strongly dependent on the reaction of the system under some predictable condition. However, it is not possible to assess the reaction of the system with distinct certainty, as the various components of the system are subject to different kinds of uncertainty. Uncertainty refers to the condition or variable, which is not able to be quantified exactly. Any uncertain variable in nature has random characteristics and it is subject to a particular level of error. In this study, the Monte Carlo simulation and Latin hypercube sampling, as two significant sampling techniques, were used to quantify the 10 uncertainty of desired uncertain random variables. These methods can be classified into analytically and approximation techniques. As deriving probability density function (PDF) of desire random variables accurately is difficult, hydrosystem engineers prefer to use approximation techniques to perform uncertainty analysis and so MCS and LHS techniques have been used through this study (Tung et al., 2005).

\subsection{Monte Carlo simulation (MCS)}

Simulation can be defined as the imitation of a real thing or process to replicate the behavior of a system under different conditions. Simulation allows to evaluate various strategies, manage the system in the best way and see how it can be changed in the future. One of the most famous simulation techniques is Monte Carlo (MC) which is based on iteration and generation of random variables from a specific range. In other word, it is a numerical simulation which replicates stochastic input random variables based on a specific probability distribution (Tung et al., 2005). The Monte Carlo simulation is frequently used for risk and reliability analysis, especially when the input variables are uncertain. Monte Carlo uses probability distribution which includes a range of values for all uncertain inputs instead of the deterministic value of variables. However, there are two major concerns with Monte Carlo simulation; at the first it needs large

HESSD

8, 9757-9796, 2011

Evaluation dam overtopping risk

E. Goodarzi et al.

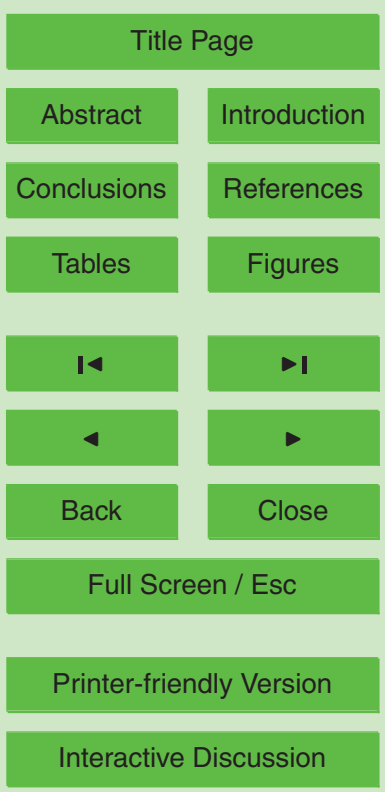

Interactive Discussion

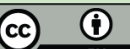


computations to generate random values, and at the second it requires large number of iterations to find accurate results.

\subsection{Latin hypercube sampling (LHS)}

There have been some reduction variance techniques to raise the precision of the is one of the main variance reduction techniques that can increase the efficiency of the output statistics parameters. In the LHS method, when sampling a function with $M$ variables, each range of variables is divided into non-overlapping ranges with the equal probability of occurrence $1 / M$. For any desire probability distribution, LHS extracts a random number from each range without repetition. The order of selection range is randomized and the model is executed $M$ times with the random combination of basic variables from each range for each basic variable (Singh et al., 2007). The convergence of LHS is quicker than the Monte Carlo simulation and also other sampling techniques such as antithetic-variate or control variates. The general algorithm for sampling of $k$ independent random variables by the LHS technique can be summarized as follows:

1. Divide the range of input variables into $m$ parts,

2. Generate $M$ uniform random number from $U(0,1 / M)$,

3. Generate random variates for each of the random variables $\left(x_{i, j}\right)$ by applying following equation:

$x_{i, j}=F_{j}^{-1}\left(\frac{1}{m}\left[P_{i, j}-r_{i, j}\right]\right)$

Where $r_{i, j}$ and $P_{i, j}$ are random number and random permutation, respectively (Kwon and Moon, 2006).
HESSD

8, 9757-9796, 2011

Evaluation dam overtopping risk

E. Goodarzi et al.

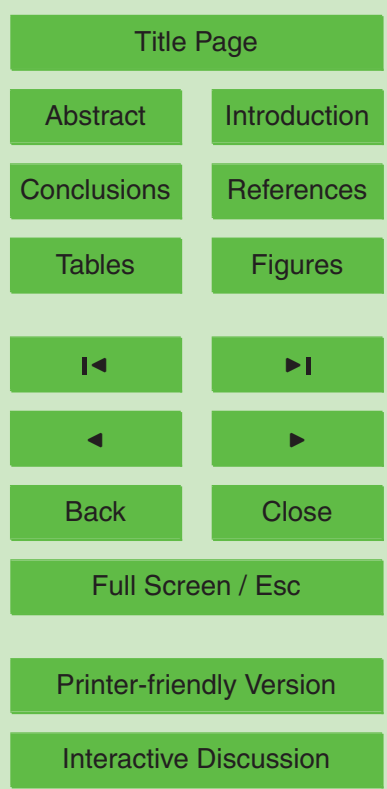


4. Performing random permutation for all random variables and calculate the performance function $Z$ for all of generated random variables.

\section{Case study}

Doroudzan dam is one of the most important dams in the Fars province in the south 5 of Iran. The basin of the multipurpose earth filled dam is situated near the North West of Shiraz on the Kor River and in the Bakhtegan lake catchment area. The Kor river watershed is between longitude $51^{\circ} 43^{\prime}$ and $52^{\circ} 54^{\prime}$ east and latitude $30^{\circ} 08^{\prime}$ and $31^{\circ} 00^{\prime}$ latitudes. The elevation of the highest point elevation of the watershed is $3749 \mathrm{~m}$ from the mean sea level and is located in the northwest of the watershed. The total volume 10 and dead storage of the reservoir are 993 and $133 \mathrm{MCM}$, respectively. Some basic information concerning Doroudzan dam and the schematic view of its basin are shown in Table 1 and Fig. 1, respectively.

Doroudzan supplies the necessary water for 112000 hectares of agricultural land and provides the domestic and industrials needs of Shiraz (the capital of Fars province), 15 Marvdasht, and Zarghan. The most important artifacts located downstream of the Doroudzan dam are the Pasargadae and Persepolis monuments, which date back to $515 \mathrm{BC}$. These structures are among the most famous monuments in the world and are visited annually by many people from all over the world. Therefore, any problems with the Doroudzan dam will undoubtedly immerse these two ancient and valuable heritage 20

\subsection{Outlier test}

In the first step of this study, an outlier test was applied for 34-yr (1975-2008) annual maximum discharges to determine the data which are departed from the trend line. Without the outlier test, the data point will not follow the trend of the assumed population

\section{HESSD}

8, 9757-9796, 2011

\section{Evaluation dam overtopping risk}

E. Goodarzi et al.

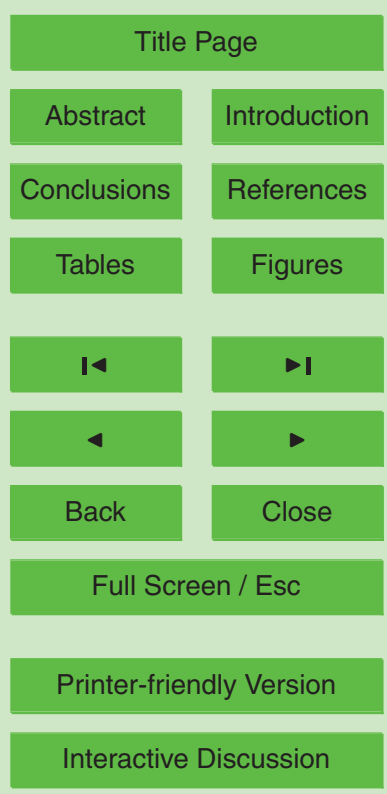


outlier) was implemented using the Bulletin 17B approach (McCuen, 2005). The results of this test show that there is a low event datum and so it is omitted from the annual maximum flood series. Therefore, the number of used data was reduced to 33 .

\subsection{Determination of uncertainty factors}

5 The considered uncertainty parameters in this study are as follows:

1. Quantile of flood peak discharge $\left(Q_{\mathrm{p}}\right)$ corresponding to 100 -yr return period only in univariate frequency analysis; the flood uncertainty may happen due to data recording, lack of data, and existence of lateral inflow to reservoir. The values of mean and standard deviation of peak discharges for flood with 50, 100, 200-yr return period are presented in Table 2. Mean and standard deviation of quantile of flood peak discharge $\left(Q_{p}\right)$ were computed based on the bulletin 17B procedure for confidence intervals (McCuen, 2005) and the maximum, minimum, and mean hydrographs for flood with 100-yr return period is shown in Fig. 2. Note that, for some hydraulic structures (e.g. bridges), flood peak discharge is a key design parameter. However, this is not true for reservoirs. To carry out reservoir flood routing, it is necessary to use complete inflow hydrograph as input. Hence, the generated peak discharges were distributed into a unit hydrograph, to produce the complete hydrograph for the reservoir routing.

2. Initial water level $\left(H_{0}\right)$; the average depth of water in the reservoir has been computed by the observed and recorded water elevation through $33 \mathrm{yr}$ during the rainy season (October-March, 1975-2008). The mean and standard deviation of initial water depth were $43.16(\mathrm{~m})$ and $1.63(\mathrm{~m})$, respectively. In addition to that, three more depths $(47,50$, and $52 \mathrm{~m}$ ) have been assumed as the initial depths in order to consider the effect of changing initial water depth on the probability of overtopping.
HESSD

8, 9757-9796, 2011

\section{Evaluation dam} overtopping risk

E. Goodarzi et al.

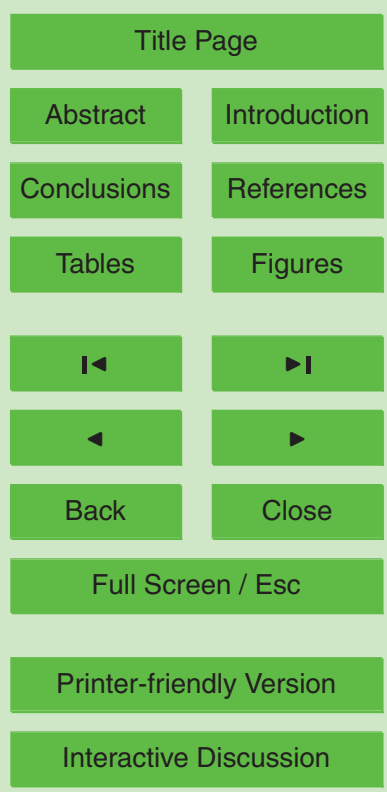


3. Spillway discharge coefficient $(C)$. Its mean and standard deviation has been determined 2.05 and 0.069, respectively based on the Doroudzan Dam Technical Reports.

\section{Flood frequency analysis}

5 Univariate and bivariate flood frequency analysis was carried out using the Gumbel logistic and Normal distributions. A goodness-of-fit test was applied for the peak flood discharges $\left(Q_{\mathrm{p}}\right)$, their corresponding direct runoff volumes $(V)$, and initial water levels $\left(H_{0}\right)$ using Chi-square test. The result of test are presented in the Table 3.

Based on the Table 3, the null hypothesis which is defined as the underlying distribu10 tion of this flood characteristics are the Gumbel logistic and Normal distributions at the significance level of 0.05 , were not rejected. In addition, Figs. 3 to 5 show the P-P plot for $H_{0}, Q_{\mathrm{p}}$, and $V$, respectively based on the adopted probability distributions in this study. A P-P plot is probability-probability plot or percent-percent plot and it applies to assess how closely two data sets agree.

\section{Bivariate flood frequency}

Equations (1) to (10) provide the CDF of annual flood events using bivariate Gumbel logistic distribution. A set of $Q_{p}-V$ pairs were computed with same joint return period curves and they were graphed with the observed values in Fig. 6. The computation related to the event that either $Q_{p}$ or $V$ or both are exceeded was the fundament of the joint return period of peak $Q_{\mathrm{p}}$ and $V$ based on Eq. (10).

As is shown in Fig. 6, the joint return period curves can be extend asymptotically along the axes but based on physical significance of data, a finite extension is acceptable and so they should be bounded by upper and lower limits. Hence, the curves were limited by lines passing through the origin with the maximum and minimum slopes of
HESSD

8, 9757-9796, 2011

Evaluation dam overtopping risk

E. Goodarzi et al.

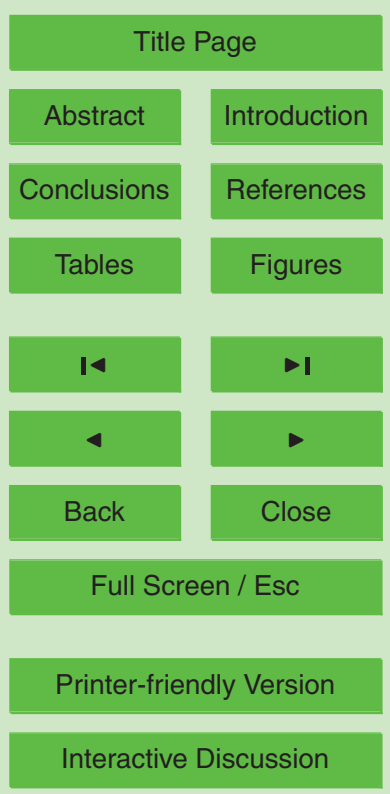


In this study, six cases $(Q-V 1$ to $Q-V 6)$ with their corresponding characteristic values were assumed and the respective hydrographs were determined using the Aldama and Ramirez (1999) method. The appropriate relations of their method to generate desire hydrographs are:

$Q\left(t ; Q_{\mathrm{p}}, t_{\mathrm{p}}, V\right)= \begin{cases}Q_{\mathrm{p}}\left[3\left(\frac{t}{t_{\mathrm{p}}}\right)^{2}-2\left(\frac{t}{t_{\mathrm{p}}}\right)^{3}\right] & t \in\left[0, t_{\mathrm{p}}\right] \\ Q_{\mathrm{p}}\left[1-\frac{3\left(t-t_{\mathrm{p}}\right)^{2}}{\left(2 V Q_{p}^{-1}-t_{\mathrm{p}}\right)^{2}}+\frac{2\left(t-t_{\mathrm{p}}\right)^{3}}{\left(2 V Q_{p}^{-1}-t_{\mathrm{p}}\right)^{3}}\right] & t \in\left[t_{\mathrm{p}}, t_{\mathrm{b}}\right] \\ 0 & t \in(-\infty, 0) \cup\left(t_{\mathrm{b}}, \infty\right)\end{cases}$

where $t_{\mathrm{p}}$ and $t_{\mathrm{b}}$ are time to peak and base time of hydrograph, respectively and can be computed as follow (Chow, 1964);

$t_{\mathrm{p}}=\frac{2 V}{3 Q_{\mathrm{p}}}$

$t_{\mathrm{b}}=3 t_{\mathrm{p}}$

The resulted hydrographs using the above equations and the ranges of peak discharge obtained from the bivariate analysis with the related series of volumes were presented in Fig. 7 and Table 4, respectively.

As available length of recorded data was limited to $33 \mathrm{yr}$, forecasting may be subjected to high uncertainty for high return periods, and so only the return period of $100 \mathrm{yr}$ have been considered in this study.

As it can be seen from Fig. 7, the main differences among the resulted hydrographs were in their peak discharges and base time of hydrographs. For example, the hydrograph $Q-V 1$ has smallest peak discharge with a relatively large flood volume and consequently with long base time, whereas hydrograph $Q-V 6$ has a highest peak discharge with a relatively short base time and smaller volume. In the following part, the probability of overtopping for all generated hydrographs from bivariate and univariate flood frequency analyses were evaluated and the worst condition that can occur was obtained for desire case study.
HESSD

8, 9757-9796, 2011

\section{Evaluation dam overtopping risk}

E. Goodarzi et al.

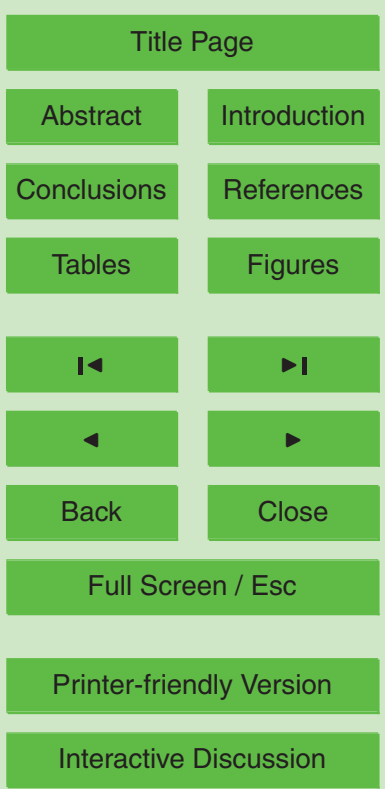

Interactive Discussion 


\section{Overtopping risk based on univariate flood frequency}

Based on the above equations, the probability of overtopping was calculated for flood of $100-y r$ return period with consideration quantile of flood peak discharge, initial water level, and the spillway discharge coefficient as uncertain variables and using Monte5 Carlo simulation and Latin hypercube sampling with a sample size of 2000 for uncertainty analysis. To generate inflow hydrographs, a peak discharge was chosen randomly based on the selected probability distribution and MCS (or LHS) method, and then this random value was distributed within a unit hydrograph to evaluate the desire inflow hydrograph.

10 The probability of overtopping due to floods in 100-yr return period and different initial levels are presented in Table 5. Based on Table 5, by increasing the initial water level in each step, the probability of overtopping (in a constant return period) was raised for both uncertainty approaches adopted in this study.

\section{Overtopping risk based on bivariate flood frequency}

15 Univariate flood frequency analysis often focuses on flood peak values and hence provides a limited assessment of flood events. This method generates a single hydrograph that can cover only one of many possible hydrographs which could be produced in the basin. While, hydrological phenomena are function of more than one correlated characteristic that they are not generally independent and should be jointly considered. So, the bivariate analysis was applied to evaluate joint distributions considering $Q_{p}-V$ combinations and consider more inflow hydrographs for risk and uncertainty analyses. Hence, the overtopping risks due to different flood 100-yr return period in four initial water levels $(43.16,47,50,52 \mathrm{~m})$ were evaluated by MCS and LHS uncertainty approaches and the results have been presented in Tables 6 and 7, respectively.

25 According to Tables 6 and 7, initial water levels are found to significantly influence the dam overtopping risk and the overtopping risk increases with initial water levels using both uncertainty analysis methods adopted in this study.

\section{HESSD}

8, 9757-9796, 2011

Evaluation dam overtopping risk

E. Goodarzi et al.

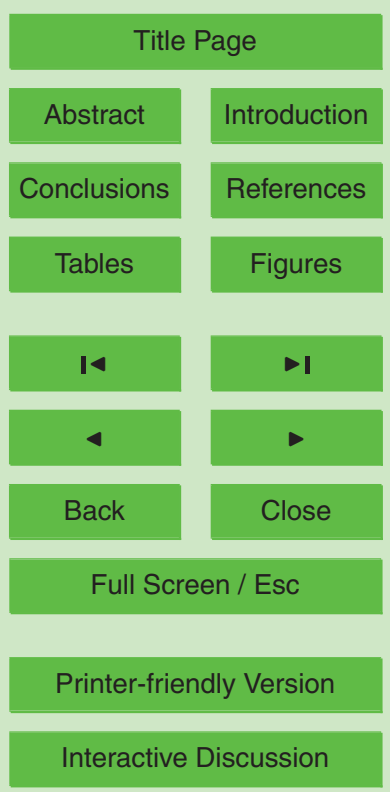


In addition, Figs. 8 and 9 show the trend of variation overtopping risks versus the initial depth of flow for univariate $Q_{\mathrm{u}}$ and all bivariate inflow hydrographs except $Q V-4$ and $Q V-5$.

Although, the trends of the risk curves computed by the different inflow hydrographs 5 and uncertainty analysis methods are similar, the values of risk regarding to bivariate flood frequency analysis are greater than the univariate frequency risk results.

Furthermore, the hydrographs with greater runoff volume $(Q-V 1$ and $Q-V 2)$ have been produced greater risks rather than other inflow hydrographs. Figures 10 to 13 show the univariate and bivariate inflow hydrographs in conjunction with the correspon10 dent overtopping risk for $Q-V 1, Q-V 6, Q-V 2$, and $Q-V 5$. This figures demonstrate that the values of overtopping risks using univariate frequency analysis in both MCS (Figs. 10 and 11) and LHS (Figs. 12 and 13) methods are less than the results of bivariate for all initial levels of water.

\section{Conclusions}

15 This paper demonstrated the process of estimating risk of overtopping based on univariate and bivariate flood frequency analyses with considering different uncertainty variables for Doroudzan earth-fill dam in south area of Iran. The selected uncertainty methods (MCS and LHS) are categorized as sampling techniques and they are the most widely used method by hydrosystem engineers. Considering the uncertain input variables, such as quantile of flood peak discharge, initial levels of water and discharge coefficient, resulted in an expand range of overtopping risks in comparison to deterministic analyses which using only the best estimate inputs and provides a single point as output. In addition, univariate and bivariate flood frequency analyses were carried out using the Gumbel logistic distribution and six possible hydrographs with different $Q_{\mathrm{p}}$ and $V$ pairs under a joint return period of 100-yr have been determined. The results demonstrated that the estimated overtopping risks based on bivariate flood frequency produce greater risks rather than univariate method.

\section{HESSD}

8, 9757-9796, 2011

\section{Evaluation dam overtopping risk}

E. Goodarzi et al.

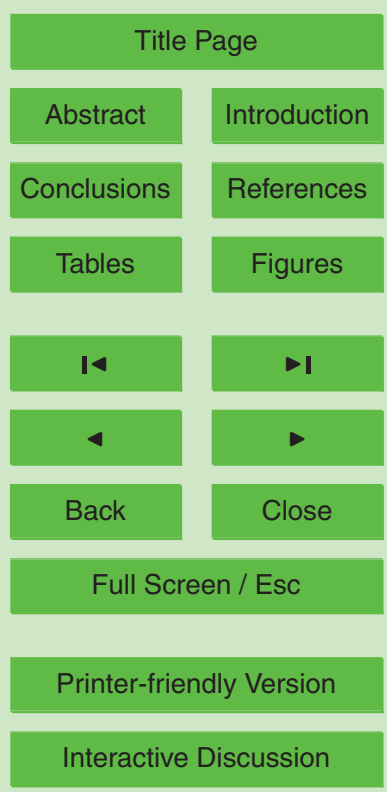


This kind of risk analysis in conjunction with uncertainty gives very important information for decision makers to have better judgments and estimates from the output variables by involving estimates of the level of confidence in risk assessment outcomes based on uncertainty in inputs. These results allow dam's administrator to identify the events that indicate a developing failure mode, and understand the critical parameters which are needed to effectively monitor.

Acknowledgements. The authors would like to acknowledge their appreciations to Eng. Naser Shokri, Eng. Hirbod Jahanbani, for helping out in one way or another during the course of this study.

\section{References}

Aldama, A. and Ramirez, A. : A new approach for dam design flood estimation, In Proceeding of the IAHR Congress, Graz, Austria, 22-27 August, 1999.

Bobee, B. and Rasmussen, P. F.: Statistical analysis of annual flood series, in: Trends in Hydrology (I), edited by: Menon, J., Council of Scientific Research Integration, India, Box, 15 G., 117-135, 1994.

Choulakian, V., El-Jabi, N., and Moussi, J.: On the distribution of flood volume in partial duration series analysis of flood phenomena, Stoch. Hydrol. Hydraul., 4, 217-226, 1990.

Chow, V. T.: Handbook of Applied Hydrology. McGrawHill, New York, 1964.

Correia, F. N.: "Multivariate partial duration series in flood risk analysis." Hydrologic frequency modeling, edited by: Singh, V. P., Reidel, Dordrecht, The Netherlands, 541-554, 1987.

Cunnane, C.: Methods and merits of regional flood frequency analysis, J. Hydrol., 100, 269290, 1988.

De Michele, C., Salvadori, G., Canossi, M., Petaccia, A., and Rosso, R.: Bivariate statistical approach to check adequacy of dam spillway, J. Hydraul. Eng., 10, 50-57, 2005.

25 Escalante, C. and Domínguez, J.: Parameter estimation for bivariate extreme value distribution by maximum entropy, Hydrol. Sci. Technol. J., 13, 1-10, 1997.

Goel, N. K., Seth, S. M., and Chandra, S.: Multivariate modeling of flood flows, ASCE, J. Hydraul. Eng., 124, 146-155, 1998.

\section{HESSD}

8, 9757-9796, 2011

Evaluation dam overtopping risk

E. Goodarzi et al.

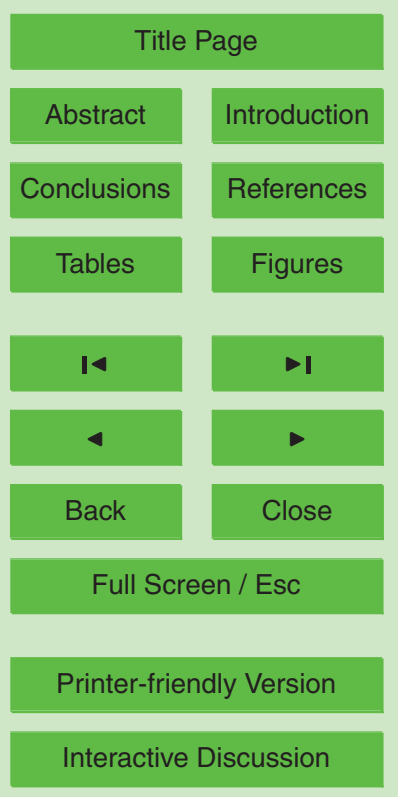


Gumbel, E. J. and Mustafi, C. K.: Some analytical properties of bivariate extreme distributions, J. Am. Stat. Assoc., 62, 569-588, 1967.

Hable, O.: Multidimensional probabilistic design concept for the estimation of the overtopping probability of dams. PhD thesis, Technical University of Graz, Graz, Austria, 2001.

5 Johnson, N. L. and Kotz, S.: Distribution in Statistics: Continuous Multivariate Distributions, John Wiley and Sons, New York, 1972.

Kelly, K. S. and Krzysztofowicz, R.: A bivariate meta-Gaussian density for use in hy drology, Stoch. Hydrol. Hydraul., 11, 17-31, 1997.

Krstanovic, P. F. and Singh, V. P.: A multivariate stochastic flood analysis using entropy, Hydrologic frequency modeling, edited by: Singh, V. P., Reidel, Dordrecht, The Netherlands, 515-539, 1987.

Kwon, $\mathrm{H}$. and Moon, Y.: Improvement of Overtopping Risk Evaluations Using Probabilistic Concepts for Existing Dams, Springer, 20, 223-237, 2005.

Loganathan, G. V., Kuo, C. Y., and Yannaccone, J.: Joint probability distribution of stream flows and Tides in estuaries, Nordic Hydrol., 18, 237-246, 1987.

McCuen, R.: Hydrologic Analysis and Design, New Jersey: Pearson Prentice Hall, 2005.

Raynal, J. A.: Bivariate extreme value distributions applied to flood frequency analysis Ph. D. dissertation, Civil Engineering Department, Colorado State University, 1985.

Raynal, J. A. and Salas, J. D.: Multivariate extreme value distributions in hydrological analyses. Water for the future: hydrology in perspective, Proc. Rome Symp., 164, 111-119, 1987.

Sackl, B. and Bergmann, H.:A bivariate flood model and its application. Hydrologic frequency modeling, edited by: Singh, V. P., Dreidel, Dordrecht, The Netherlands, 571-582, 1987.

Salvadori, G. and De Michele, C.: Frequency analysis via copulas: Theoretical aspects and applications to hydrological events, Water Resour. Res., 40, W12511, doi:10.1029/2004WR003133, 2004.

Singh, K. and Singh, V. P. : Derivation of bivariate probability density functions with exponential marginals.", Stoch. Hydrol. Hydraul., 5, 55-68, 1991.

Singh, V., Jain, S. K., and Tyagi, A.: Risk and Uncertainty Analysis, McGraw-Hill, 2005.

Tung, Y. K. and Yen, B. C.: Hydrosystems Engineering Uncertainty Analysis, New York: Mc Graw-Hill, 2005.

Yanmaz, A. and Gunindi, M.: Assessment of overtopping reliability and benefits of a flood detention dam, Can. J. Civ. Eng., 35, 1177-1182, 2008.

Yue, S.: Applying the bivariate normal distribution to flood frequency analysis, Water Int., 24,

HESSD

8, 9757-9796, 2011

\section{Evaluation dam overtopping risk}

E. Goodarzi et al.

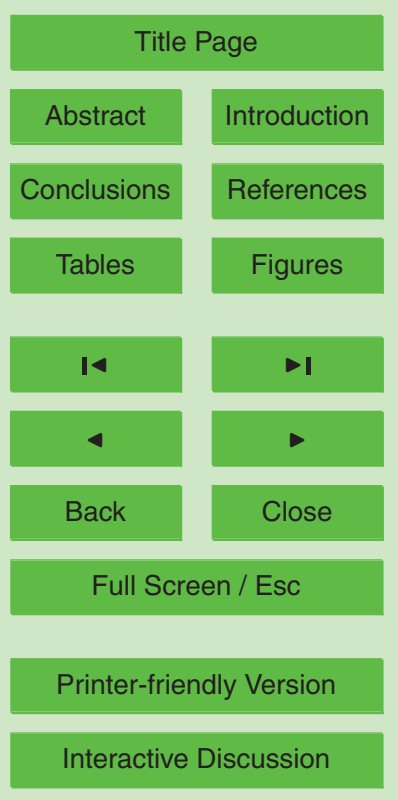

Interactive Discussion

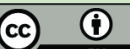


248-252, 1999.

Yue, S.: The bivariate lognormal distribution to model a multivariate flood episode, Hydrol. Process., 14, 2575-2588, 2000.

Yue, S.: A bivariate gamma distribution for use in multivariate flood frequency analysis, Hydrol. Process., 15, 1033-1045, 2001.

Yue, S. and Rasmussen, P.: Bivariate frequency analysis: Discussion of some useful concepts in hydrological applications, Hydrol. Process., 16, 2881-2898, 2002.

\section{HESSD}

8, 9757-9796, 2011

\section{Evaluation dam overtopping risk}

E. Goodarzi et al.

Title Page

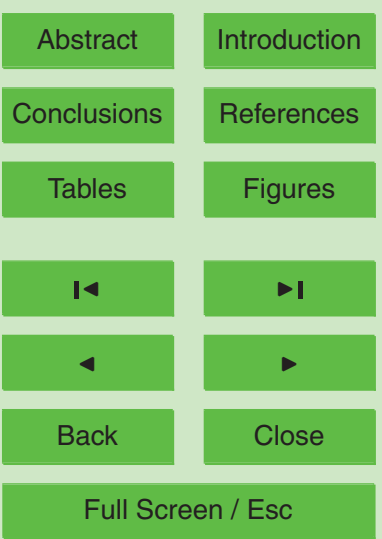

Printer-friendly Version

Interactive Discussion 


\section{HESSD}

8, 9757-9796, 2011

\section{Evaluation dam overtopping risk}

E. Goodarzi et al.

Table 1. The basic information of Doroudzan dam.

\begin{tabular}{lrll}
\hline Type & Earth-fill & Max width at base & $450 \mathrm{~m}$ \\
\hline Height & $57 \mathrm{~m}$ & Total volume & $993 \mathrm{MCM}$ \\
Crest length & $710 \mathrm{~m}$ & Foundation & Limestone rock \\
Crest width & $10 \mathrm{~m}$ & Slope of upstream & $3 \mathrm{H}: 1 \mathrm{~V}$ \\
Crest elevation & $1683.5 \mathrm{~m}$ & Slope of downstream & $3 \mathrm{H}: 1 \mathrm{~V}$ \\
\hline
\end{tabular}

Title Page

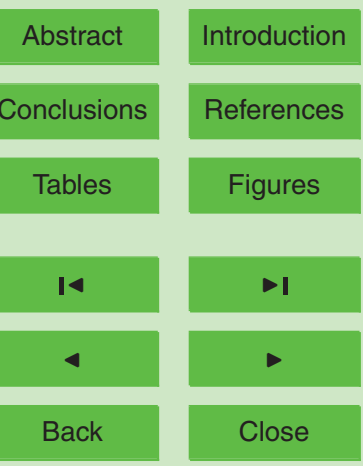

Full Screen / Esc

Printer-friendly Version

Interactive Discussion 


\section{HESSD}

8, 9757-9796, 2011

\section{Evaluation dam} overtopping risk

E. Goodarzi et al.

Table 2. Statistical parameters of peak discharges in different return periods.

\begin{tabular}{lcc}
\hline \multirow{2}{*}{ T-year } & \multicolumn{2}{c}{$Q_{\mathrm{p}}\left(\mathrm{m}^{3} \mathrm{~s}^{-1}\right)$} \\
\cline { 2 - 3 } & $\mu_{Q_{\mathrm{p}}}$ & $\mu_{Q_{\mathrm{p}}}$ \\
\hline $50-\mathrm{yr}$ & 1048.04 & 126.31 \\
$100-\mathrm{yr}$ & 1201.12 & 173.85 \\
$200-\mathrm{yr}$ & 1371.91 & 309.12 \\
\hline
\end{tabular}

Title Page

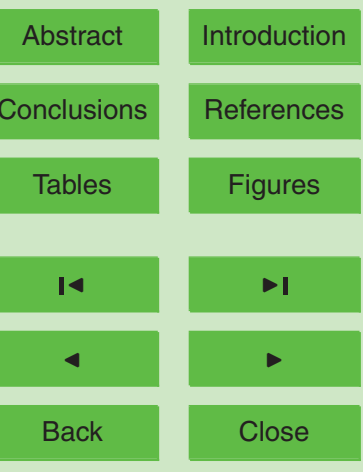

Full Screen / Esc

Printer-friendly Version

Interactive Discussion

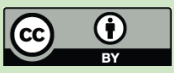




\section{HESSD}

8, 9757-9796, 2011

\section{Evaluation dam} overtopping risk

E. Goodarzi et al.

Table 3. The result of goodness-of-fit (Chi-square test).

\begin{tabular}{cccccccc}
\hline \multicolumn{3}{c}{ Gumbel logistic distribution } & & \multicolumn{3}{c}{ Normal distribution } \\
\cline { 1 - 3 } \cline { 5 - 7 } Compute & Critical & Remark & & Compute & Critical & Remark \\
3.628 & 5.991 & Ok & & - & - & - \\
4.67 & 5.991 & Ok & & - & - & - \\
- & - & - & & 10.06 & 12.59 & OK \\
\hline
\end{tabular}

Title Page

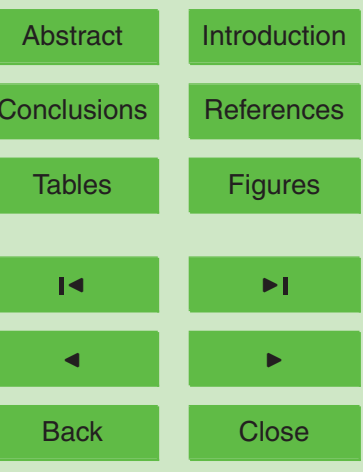

Full Screen / Esc

Printer-friendly Version

Interactive Discussion 


\section{HESSD}

8, 9757-9796, 2011

\section{Evaluation dam} overtopping risk

E. Goodarzi et al.

Table 4. The peak discharges and correspondent volumes based on bivariate frequency analysis.

\begin{tabular}{lrr}
\hline T-year & $Q_{\mathrm{p}}\left(\mathrm{m}^{3} \mathrm{~s}^{-1}\right)$ & $V(\mathrm{MCM})$ \\
\hline 50 & $962.2-3186.5$ & $275.3-502.9$ \\
100 & $1093.2-3646.2$ & $315.0-571.4$ \\
200 & $1224.3-4104.6$ & $354.6-639.9$ \\
\hline
\end{tabular}

Title Page

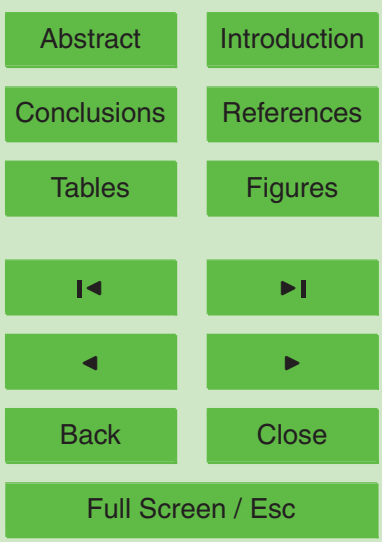

Printer-friendly Version

Interactive Discussion 


\section{HESSD}

8, 9757-9796, 2011

\section{Evaluation dam} overtopping risk

E. Goodarzi et al.

Table 5. Risk of overtopping base on univariate flood frequency analysis.

\begin{tabular}{lcccc}
\hline$H_{0}(\mathrm{~m})$ & 43.16 & 47.00 & 50.00 & 52.00 \\
\hline \multicolumn{5}{c}{ Overtopping Risk } \\
\hline LHS & $3.74 \mathrm{E}-13$ & $7.18 \mathrm{E}-08$ & $9.77 \mathrm{E}-05$ & $4.02 \mathrm{E}-03$ \\
MCS & $1.56 \mathrm{E}-13$ & $8.38 \mathrm{E}-08$ & $1.33 \mathrm{E}-04$ & $4.22 \mathrm{E}-03$ \\
\hline
\end{tabular}

Title Page

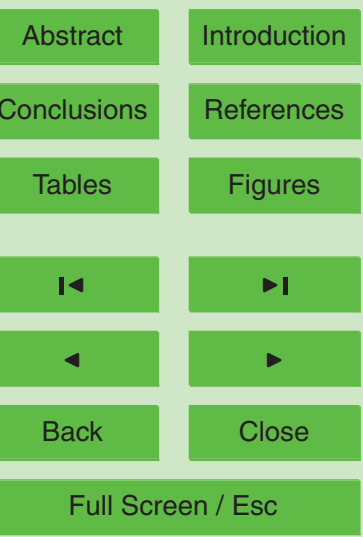

Printer-friendly Version

Interactive Discussion

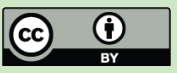




\section{HESSD}

8, 9757-9796, 2011

\section{Evaluation dam overtopping risk}

E. Goodarzi et al.

Table 6. Risk of overtopping base on bivariate flood frequency and using MCS method.

\begin{tabular}{lrrrr}
\hline$H_{0}(\mathrm{~m})$ & 43.16 & 47.00 & 50.00 & 52.00 \\
\hline \multicolumn{5}{c}{ Overtopping Risk } \\
\hline$Q-V 1$ & $3.65 \mathrm{E}-09$ & $1.78 \mathrm{E}-03$ & $1.21 \mathrm{E}-01$ & $4.96 \mathrm{E}-01$ \\
$Q-V 2$ & $3.85 \mathrm{E}-10$ & $1.15 \mathrm{E}-04$ & $2.34 \mathrm{E}-02$ & $2.36 \mathrm{E}-01$ \\
$Q-V 3$ & $9.99 \mathrm{E}-12$ & $1.90 \mathrm{E}-05$ & $8.85 \mathrm{E}-03$ & $1.10 \mathrm{E}-01$ \\
$Q-V 4$ & $8.32 \mathrm{E}-12$ & $8.61 \mathrm{E}-06$ & $5.44 \mathrm{E}-03$ & $6.85 \mathrm{E}-02$ \\
$Q-V 5$ & $5.07 \mathrm{E}-12$ & $7.36 \mathrm{E}-06$ & $4.28 \mathrm{E}-03$ & $6.66 \mathrm{E}-02$ \\
$Q-V 6$ & $1.29 \mathrm{E}-11$ & $9.05 \mathrm{E}-06$ & $4.58 \mathrm{E}-03$ & $6.87 \mathrm{E}-02$ \\
\hline
\end{tabular}

Title Page

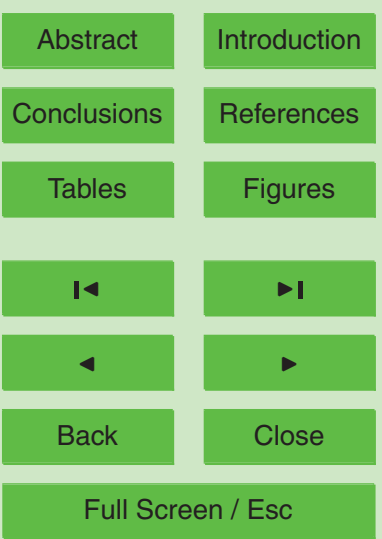

Printer-friendly Version

Interactive Discussion 


\section{HESSD}

8, 9757-9796, 2011

\section{Evaluation dam overtopping risk}

E. Goodarzi et al.

Table 7. Risk of overtopping base on bivariate flood frequency and using LHS method.

\begin{tabular}{lcccc}
\hline$H_{0}(\mathrm{~m})$ & 43.16 & 47.00 & 50.00 & 52.00 \\
\hline \multicolumn{5}{c}{ Overtopping Risk } \\
\hline$Q-V 1$ & $2.28 \mathrm{E}-09$ & $1.06 \mathrm{E}-03$ & $1.11 \mathrm{E}-01$ & $4.98 \mathrm{E}-01$ \\
$Q-V 2$ & $1.42 \mathrm{E}-10$ & $1.10 \mathrm{E}-04$ & $2.54 \mathrm{E}-02$ & $2.25 \mathrm{E}-01$ \\
$Q-V 3$ & $2.14 \mathrm{E}-11$ & $2.14 \mathrm{E}-05$ & $6.94 \mathrm{E}-03$ & $1.08 \mathrm{E}-01$ \\
$Q-V 4$ & $1.05 \mathrm{E}-11$ & $8.83 \mathrm{E}-06$ & $5.67 \mathrm{E}-03$ & $7.62 \mathrm{E}-02$ \\
$Q-V 5$ & $5.20 \mathrm{E}-12$ & $7.32 \mathrm{E}-06$ & $4.15 \mathrm{E}-03$ & $6.81 \mathrm{E}-02$ \\
$Q-V 6$ & $1.03 \mathrm{E}-11$ & $8.82 \mathrm{E}-06$ & $4.55 \mathrm{E}-03$ & $7.06 \mathrm{E}-02$ \\
\hline
\end{tabular}

Title Page

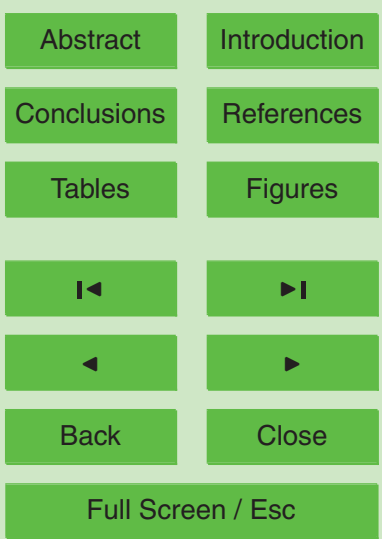

Printer-friendly Version

Interactive Discussion 
Table A1. List of Symbols.

\section{HESSD}

8, 9757-9796, 2011

\begin{tabular}{|c|c|}
\hline $\mathrm{cms}$ & Cubic meter per second \\
\hline C & coefficient of variation \\
\hline$D$ & Mean water depth along the fetch length \\
\hline$F_{x}^{-1}$ & Inverse function \\
\hline$H_{0}$ & Mean of elevation from bottom \\
\hline$H_{1}$ & Height difference between the crest of spillway and initial water level \\
\hline $\mathrm{H}_{2}$ & Height difference between the crest of dam and initial water level \\
\hline$H_{\max }$ & Height of water in the reservoir \\
\hline$H_{\mathrm{R}}$ & Height of dam \\
\hline$h$ & Depth of water from the bed to the current water elevation \\
\hline I & Inflow \\
\hline$k$ & Number of uniform random numbers \\
\hline$L$ & Load \\
\hline $\mathrm{m}$ & meter \\
\hline$m_{\mathrm{r}}$ & Parameter describing the association between two random variables \\
\hline MCM & Million cubic meters \\
\hline$P[]$. & Probability of. \\
\hline$P_{i, j}$ & Random permutation \\
\hline$Q$ & Outflow (cms) \\
\hline$Q_{\mathrm{u}}$ & $\begin{array}{l}\text { Inflow hydrograph base on the univariate flood frequency } \\
\text { analysis }\end{array}$ \\
\hline$Q_{\mathrm{p}}$ & Flood peak discharge \\
\hline$Q-V$ & Inflow hydrographs based on the bivariate flood frequency analysis \\
\hline$R$ & Resistance \\
\hline$r_{i, j}$ & Random number \\
\hline$S$ & Storage \\
\hline$t$ & Time \\
\hline$t_{\mathrm{b}}$ & Base time of hydrograph \\
\hline$t_{\mathrm{p}}$ & Time to peak \\
\hline$T$ & Return period \\
\hline$u_{i}$ & Uniform random number \\
\hline$V$ & Flood volume \\
\hline$x_{i, j}$ & Random variates \\
\hline$Z$ & Performance function \\
\hline$\Delta t$ & Time interval (s) \\
\hline$a^{\prime}$ & Risk \\
\hline$\beta$ & Reliability index indicator \\
\hline$\mu$ & Mean of variable \\
\hline$\sigma$ & Standard deviation \\
\hline$\theta$ & Slope of the dam body \\
\hline$p$ & Correlation coefficient of two variables \\
\hline$\phi$ & Cumulative normal probability \\
\hline
\end{tabular}

\section{Evaluation dam overtopping risk}

E. Goodarzi et al.

Title Page

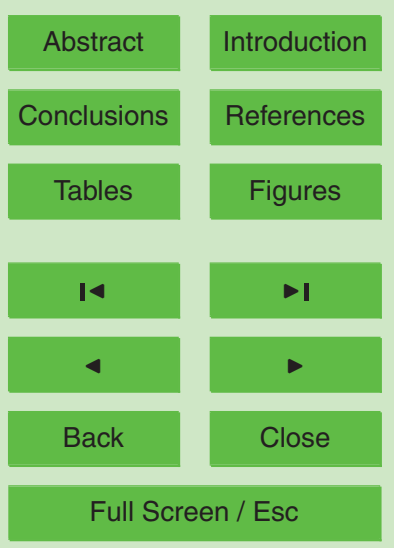

Printer-friendly Version

Interactive Discussion 


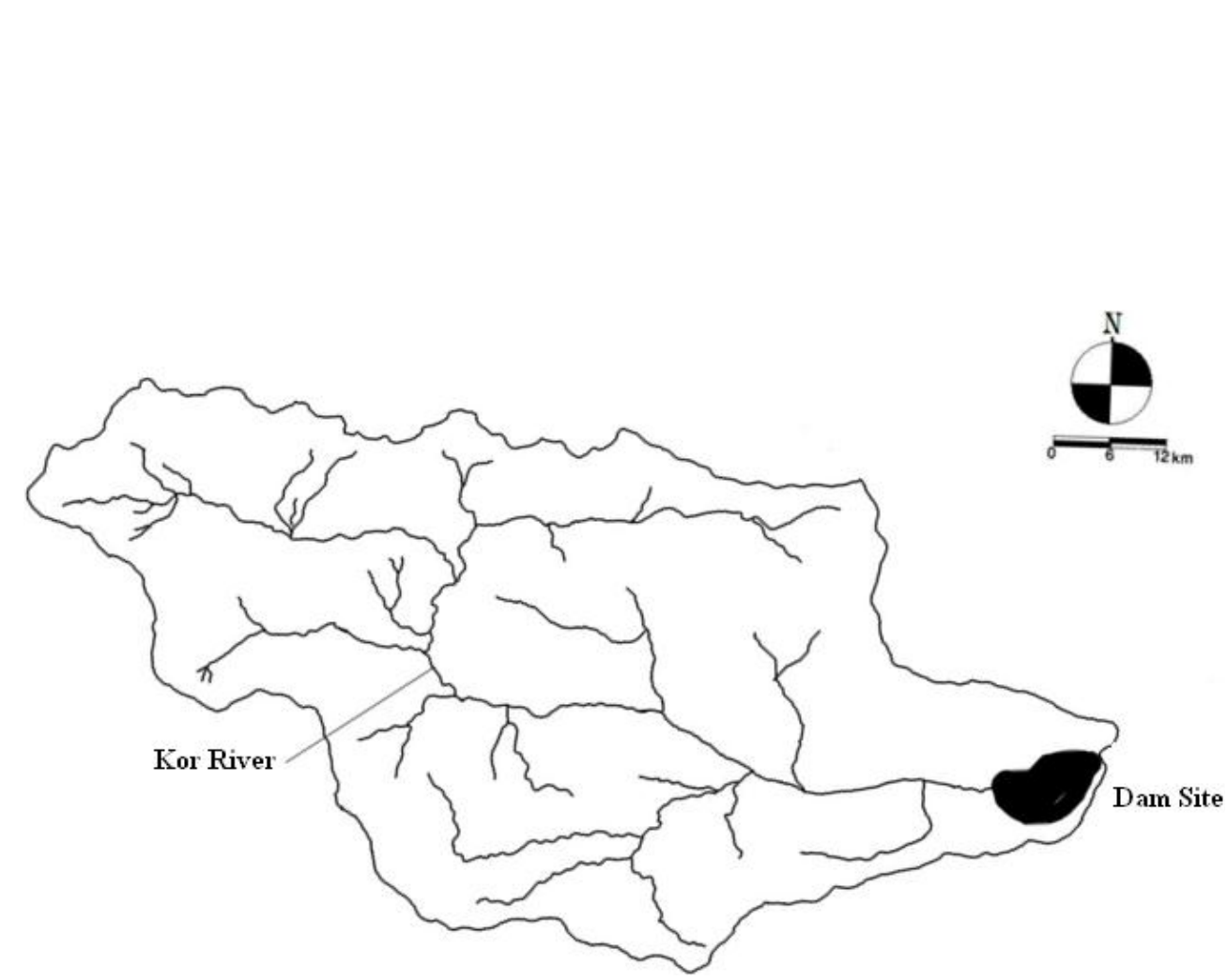

HESSD

8, 9757-9796, 2011

\section{Evaluation dam overtopping risk \\ E. Goodarzi et al.}

Fig. 1. The schematic view of Doroudzan Reservoir basin. 
HESSD

8, 9757-9796, 2011

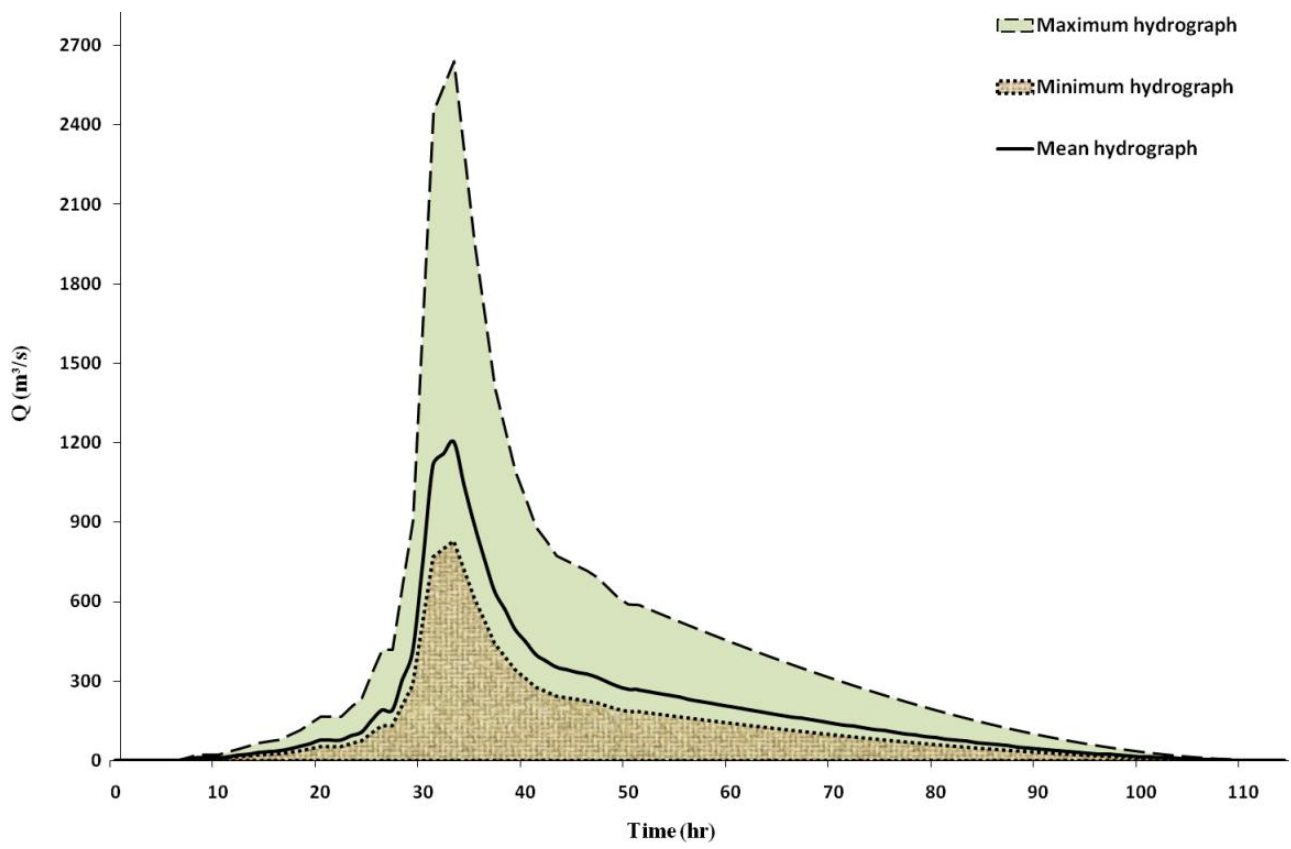

Fig. 2. The maximum, minimum, and mean of unit hydrographs with 100-yr return.

\section{Evaluation dam overtopping risk}

E. Goodarzi et al.

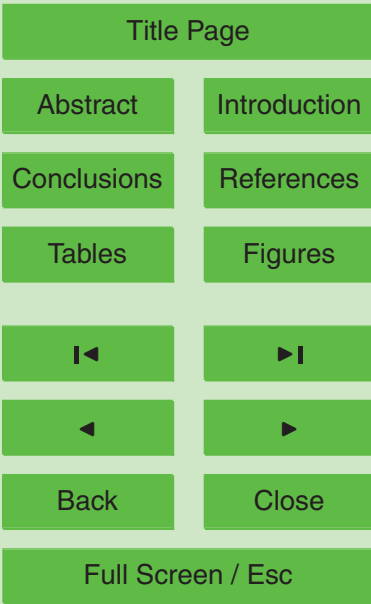

Printer-friendly Version

Interactive Discussion 


\section{HESSD}

8, 9757-9796, 2011

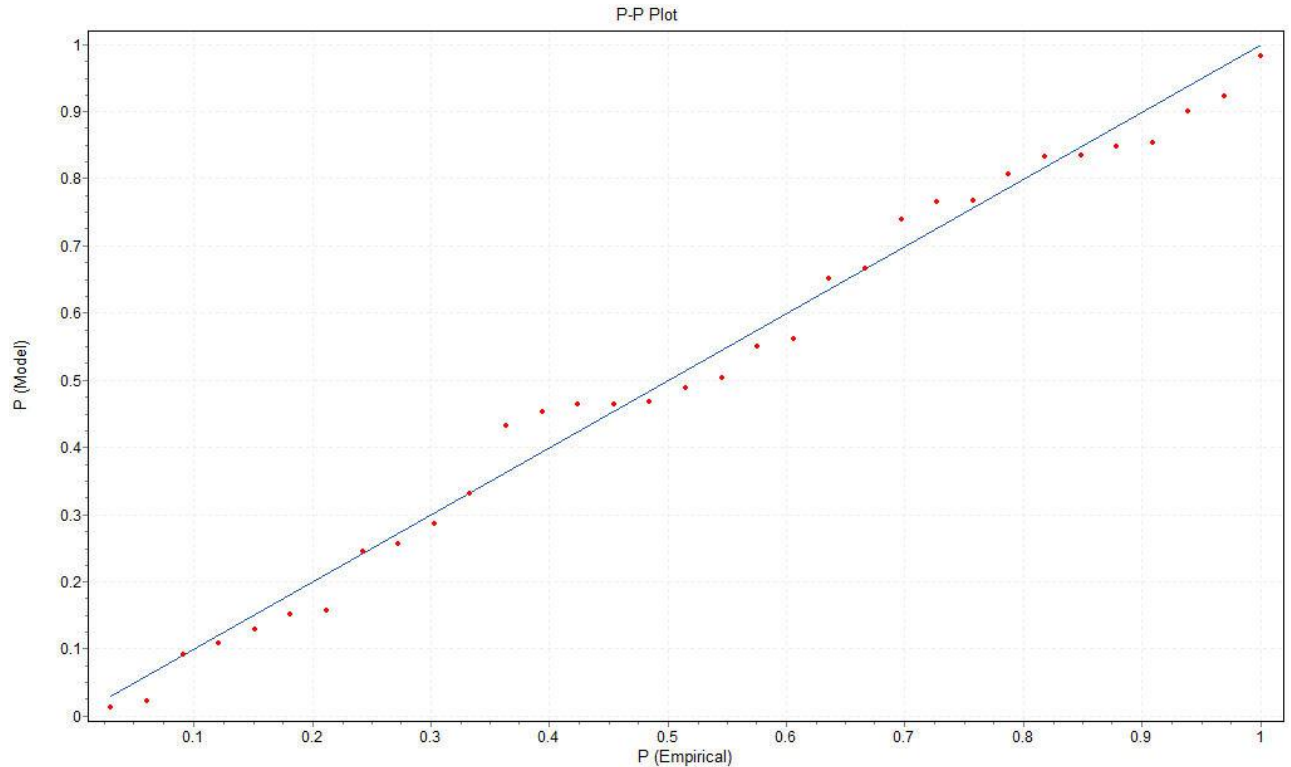

\section{Evaluation dam overtopping risk \\ E. Goodarzi et al.}

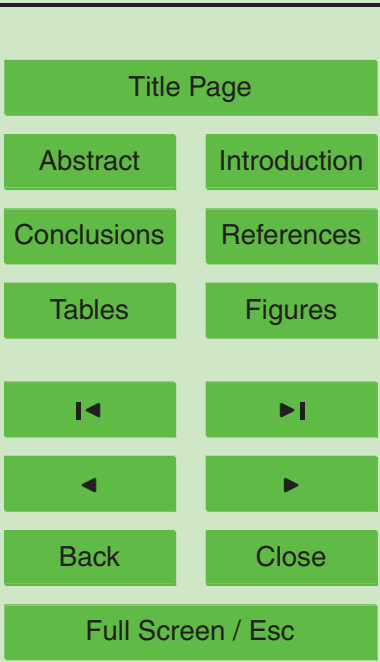

Fig. 3. Observed and predicted values of initial levels of water.

Printer-friendly Version

Interactive Discussion 


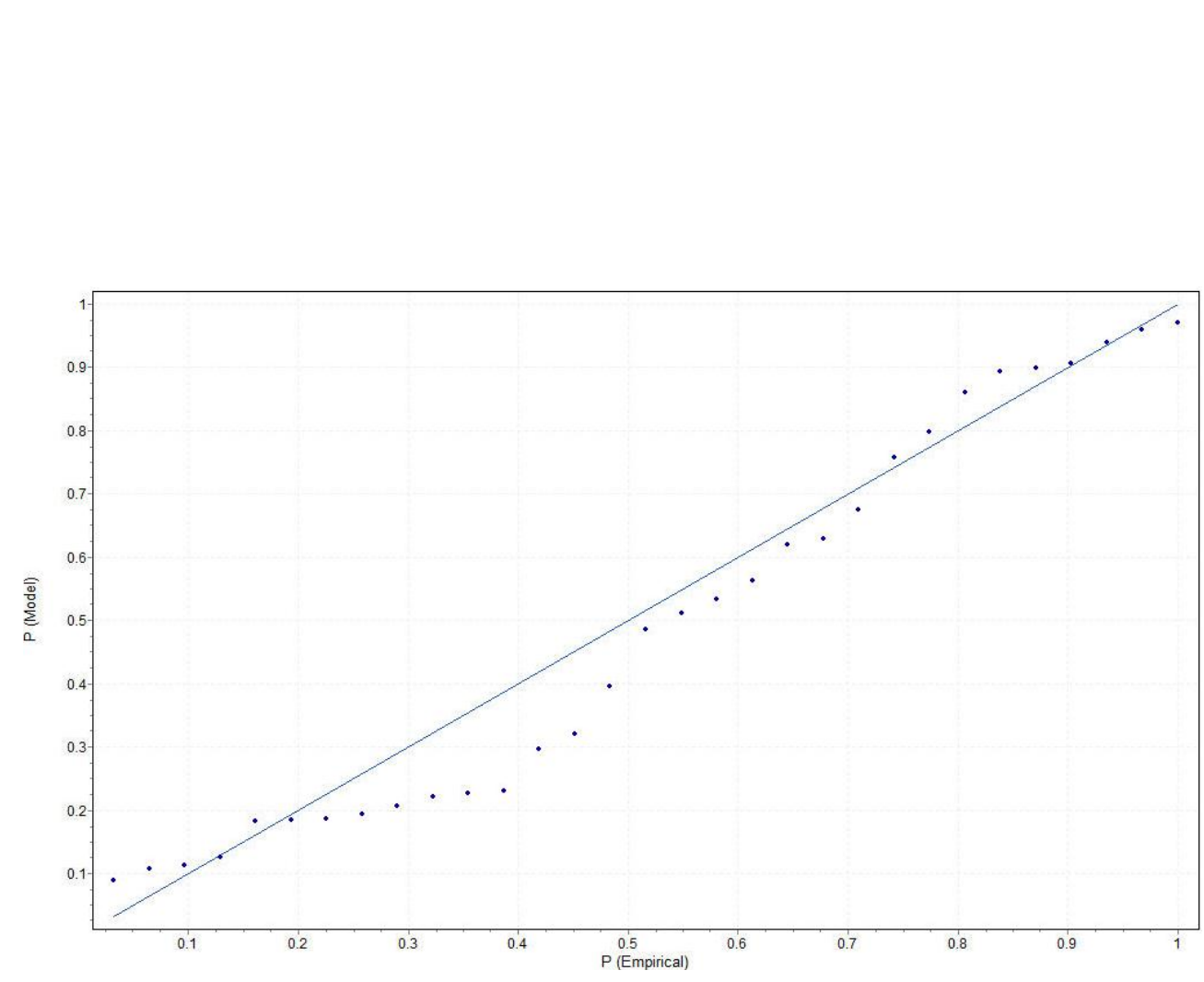

\section{HESSD}

8, 9757-9796, 2011

\section{Evaluation dam overtopping risk \\ E. Goodarzi et al.}

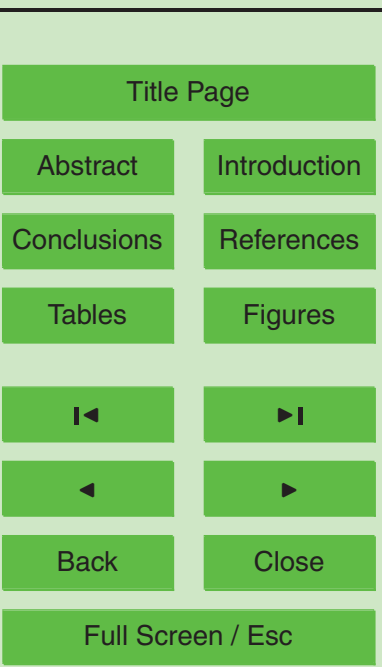

Fig. 4. Observed and predicted values of flood peak discharge.

Printer-friendly Version

Interactive Discussion

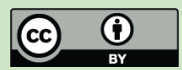




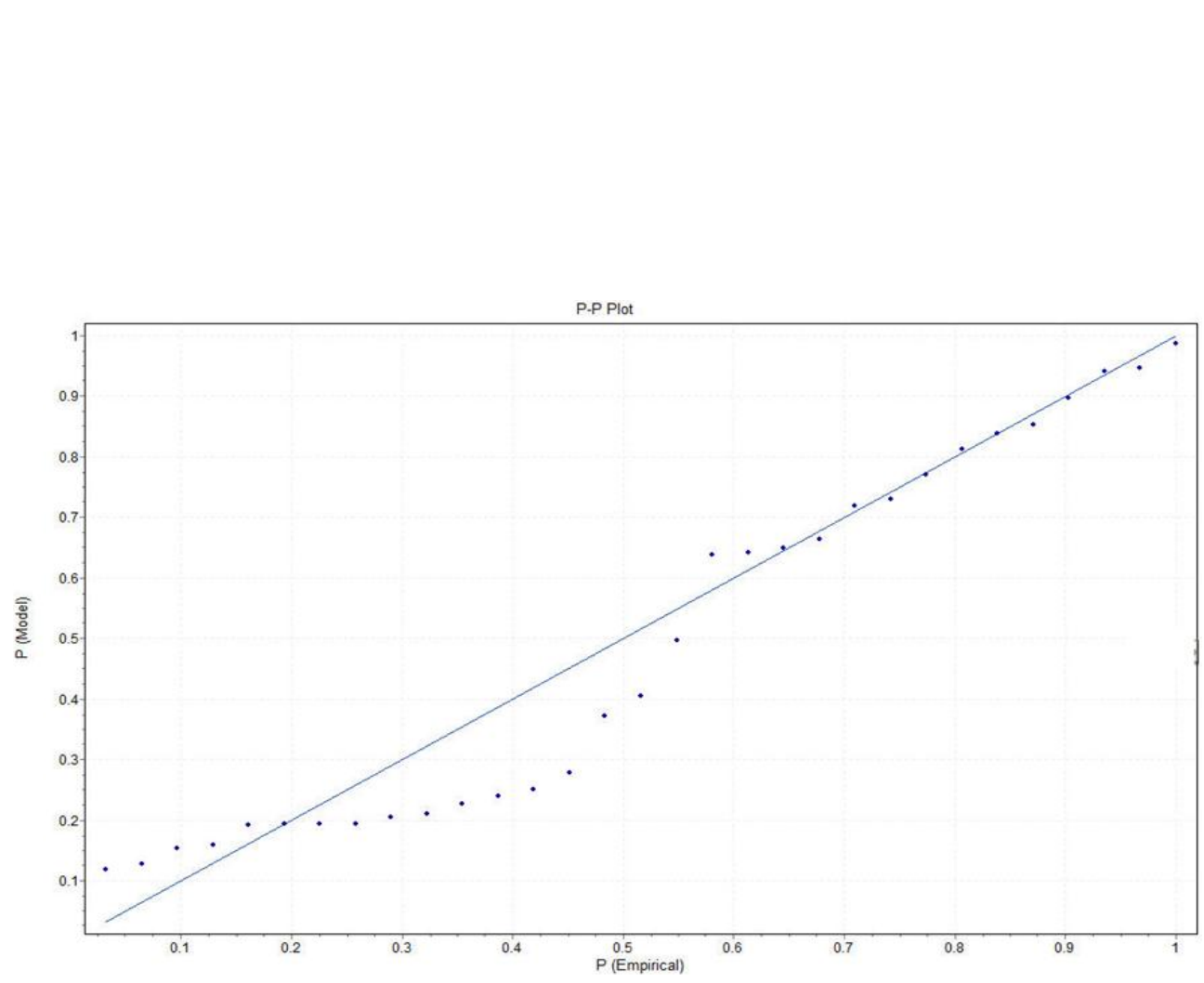

\section{HESSD}

8, 9757-9796, 2011

\section{Evaluation dam overtopping risk \\ E. Goodarzi et al.}

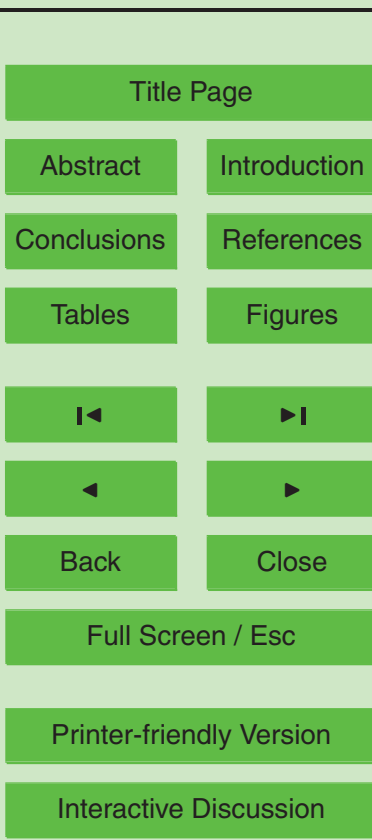

Fig. 5. Observed and predicted values of flood volume. 
HESSD

8, 9757-9796, 2011

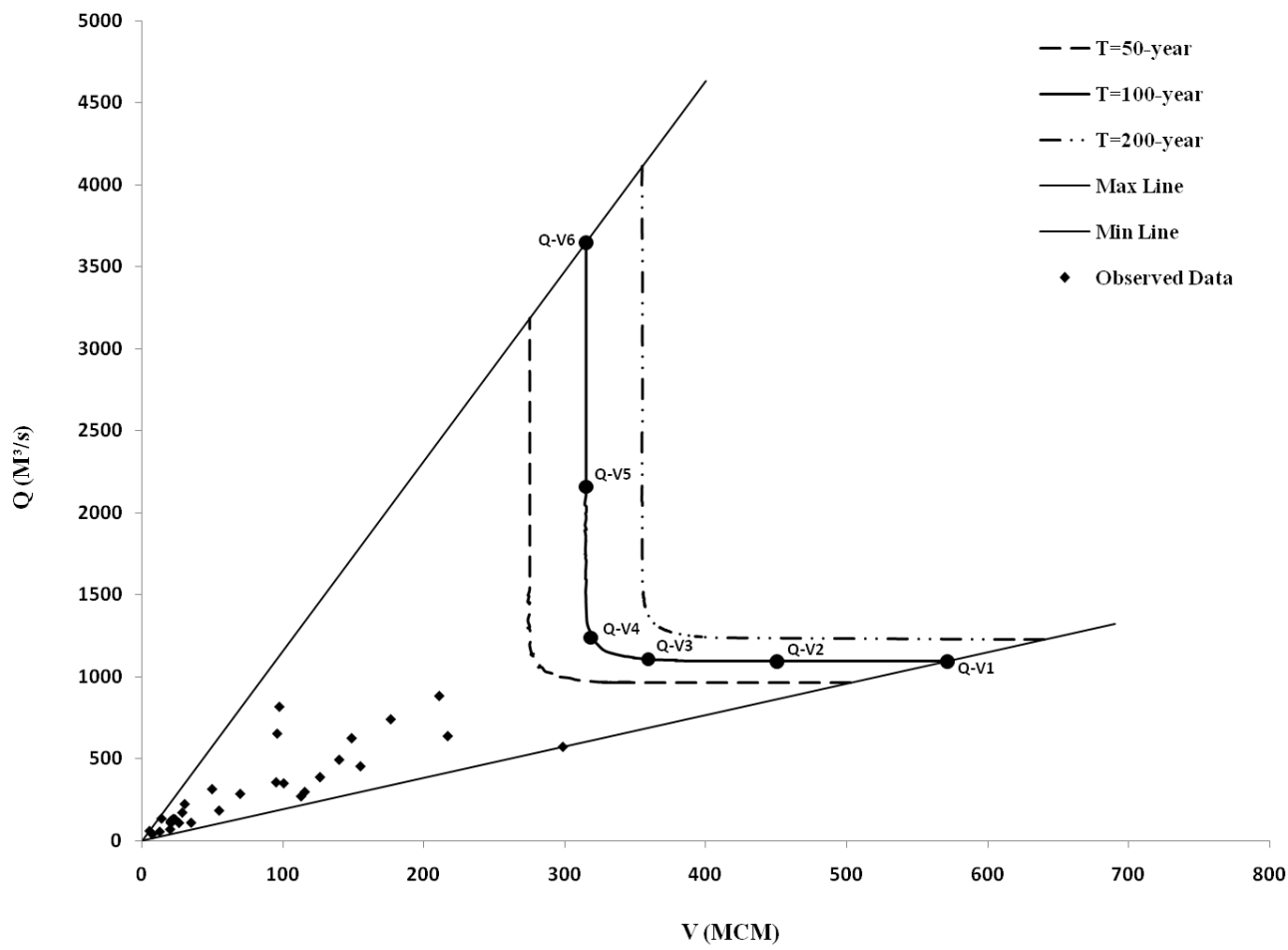

Fig. 6. Equal joint return period curves.

\section{Evaluation dam overtopping risk}

E. Goodarzi et al.

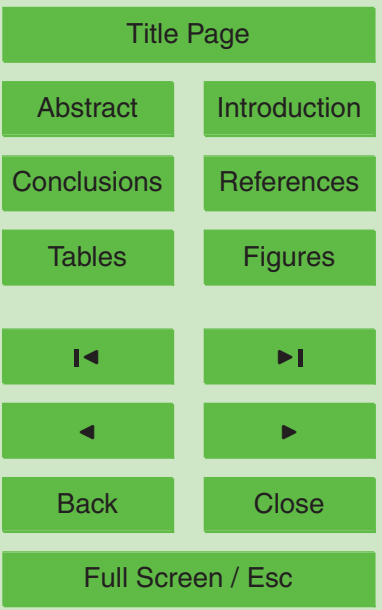

Printer-friendly Version

Interactive Discussion 
HESSD

8, 9757-9796, 2011

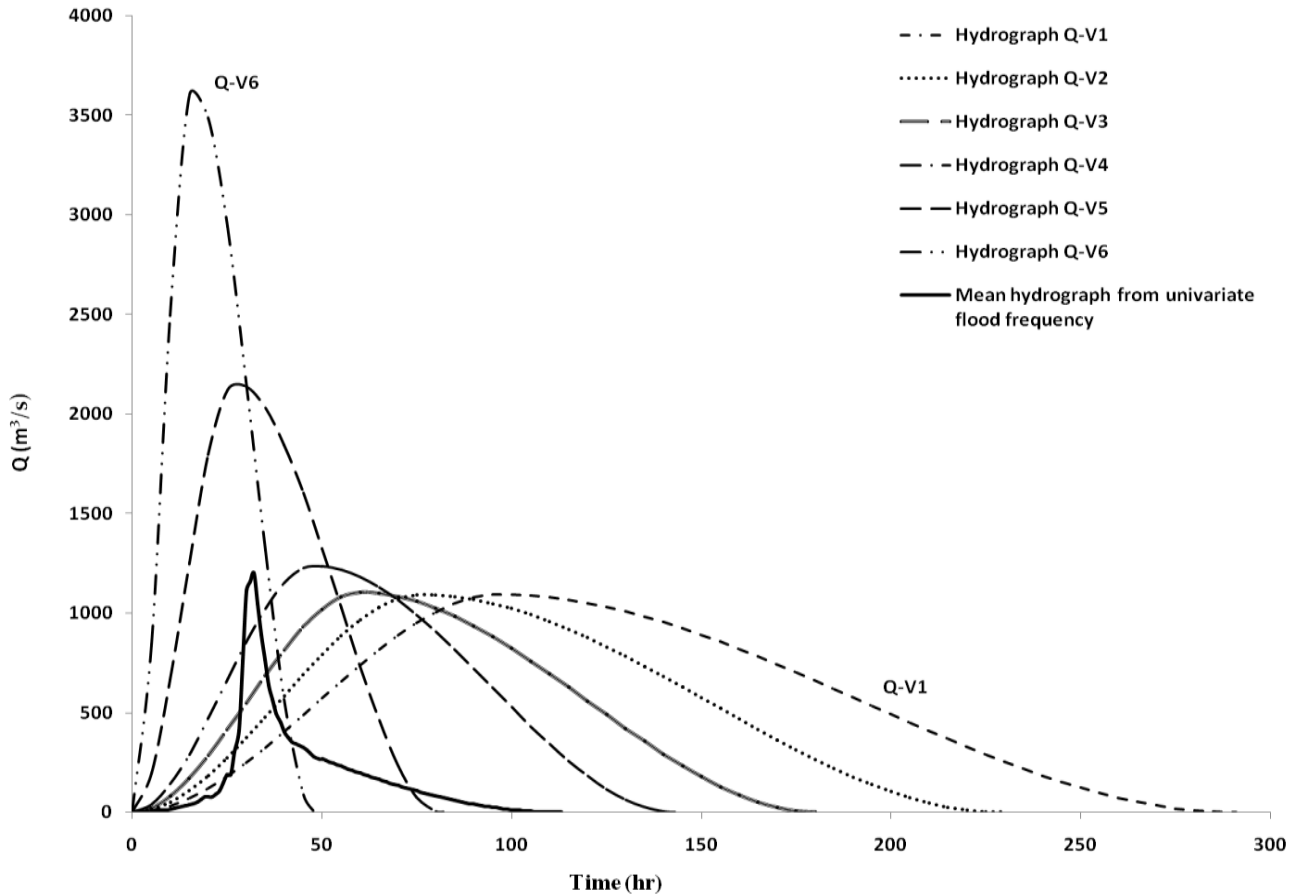

Fig. 7. The inflow hydrographs based on bivariate and univariate frequency analysis.

\section{Evaluation dam overtopping risk}

E. Goodarzi et al.

Title Page

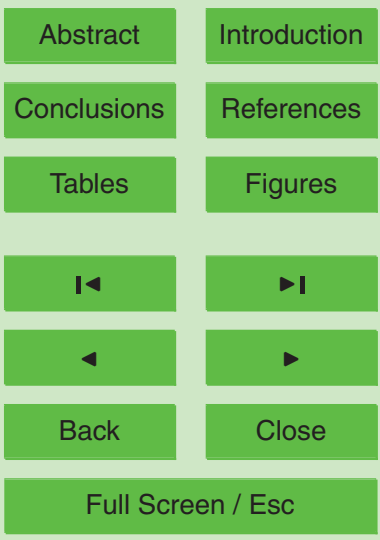

Printer-friendly Version

Interactive Discussion 


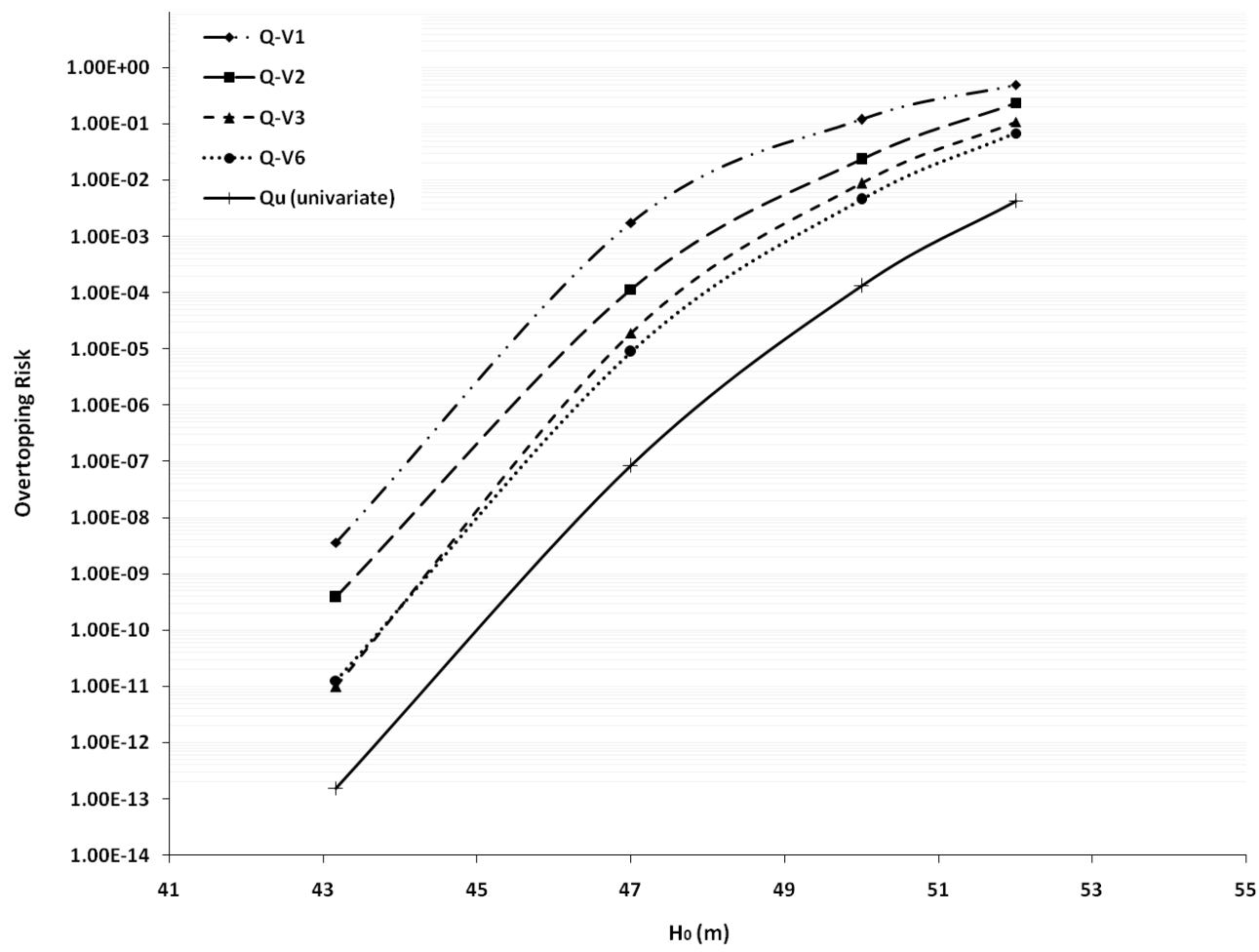

Fig. 8. Variation overtopping risk vs. initial levels of water based on MCS method.

\section{HESSD}

8, 9757-9796, 2011

\section{Evaluation dam overtopping risk}

E. Goodarzi et al.

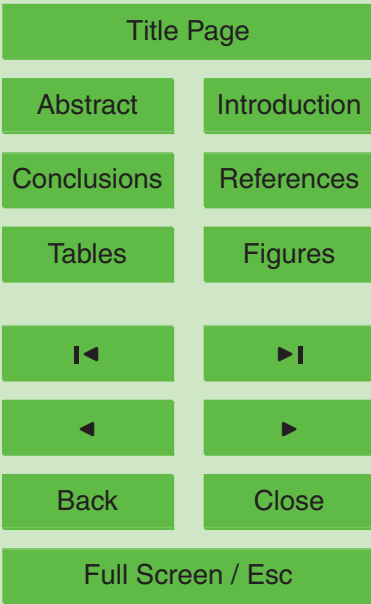

Printer-friendly Version

Interactive Discussion 


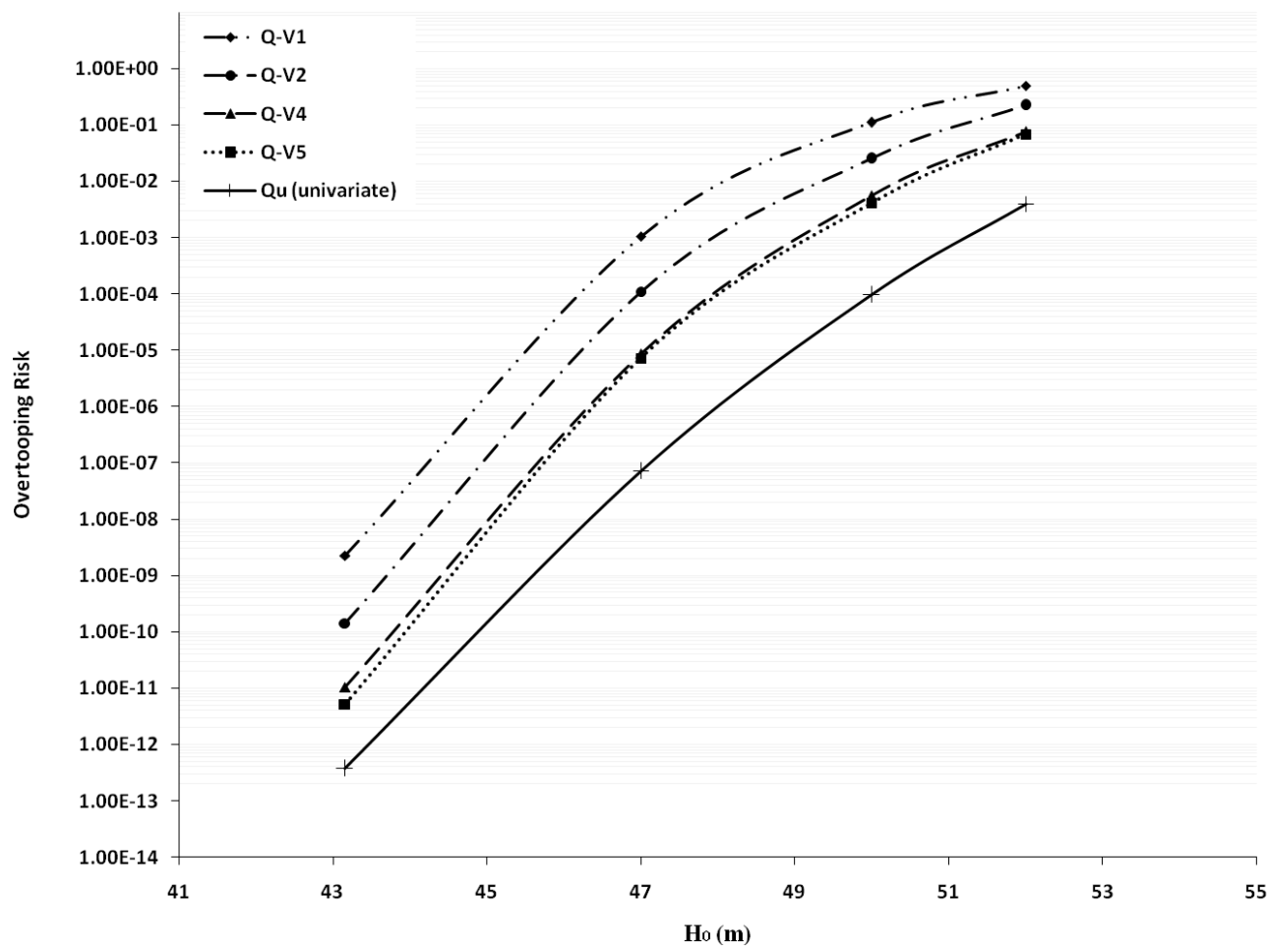

\section{HESSD}

8, 9757-9796, 2011

\section{Evaluation dam overtopping risk}

E. Goodarzi et al.

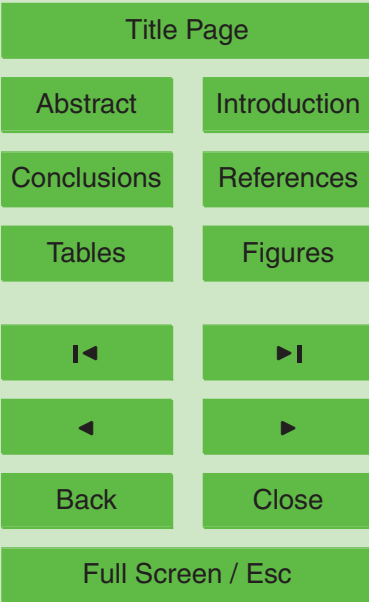

Printer-friendly Version

Fig. 9. Variation overtopping risk vs. initial levels of water based on LHS method.

Interactive Discussion

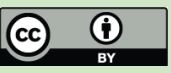


HESSD

8, 9757-9796, 2011

\section{Evaluation dam overtopping risk}

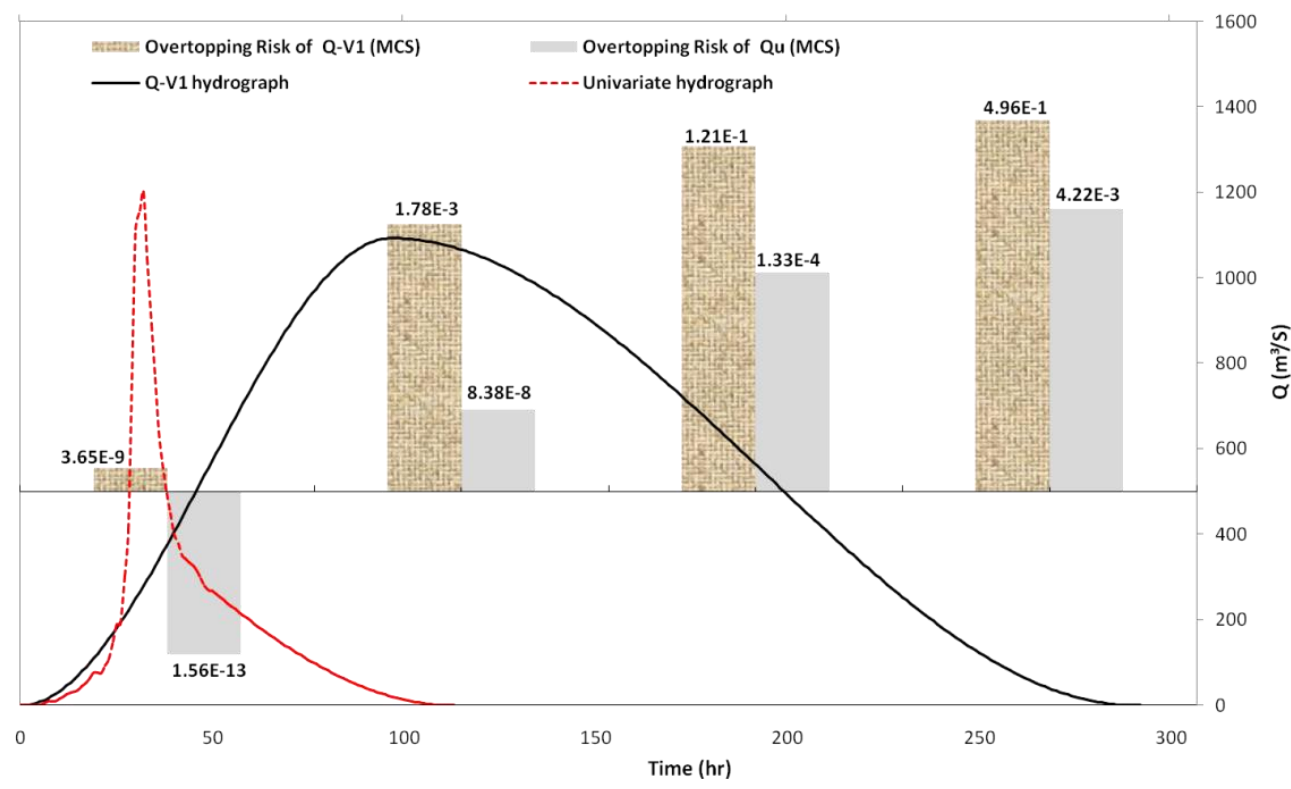

Fig. 10. Overtopping risk of $Q_{\mathrm{u}}$ and $Q-V 1$ based on MCS method.

\section{E. Goodarzi et al.}

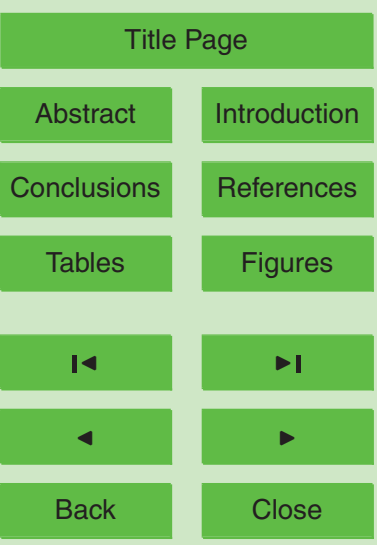

Full Screen / Esc

Printer-friendly Version

Interactive Discussion 
HESSD

8, 9757-9796, 2011

\section{Evaluation dam overtopping risk}

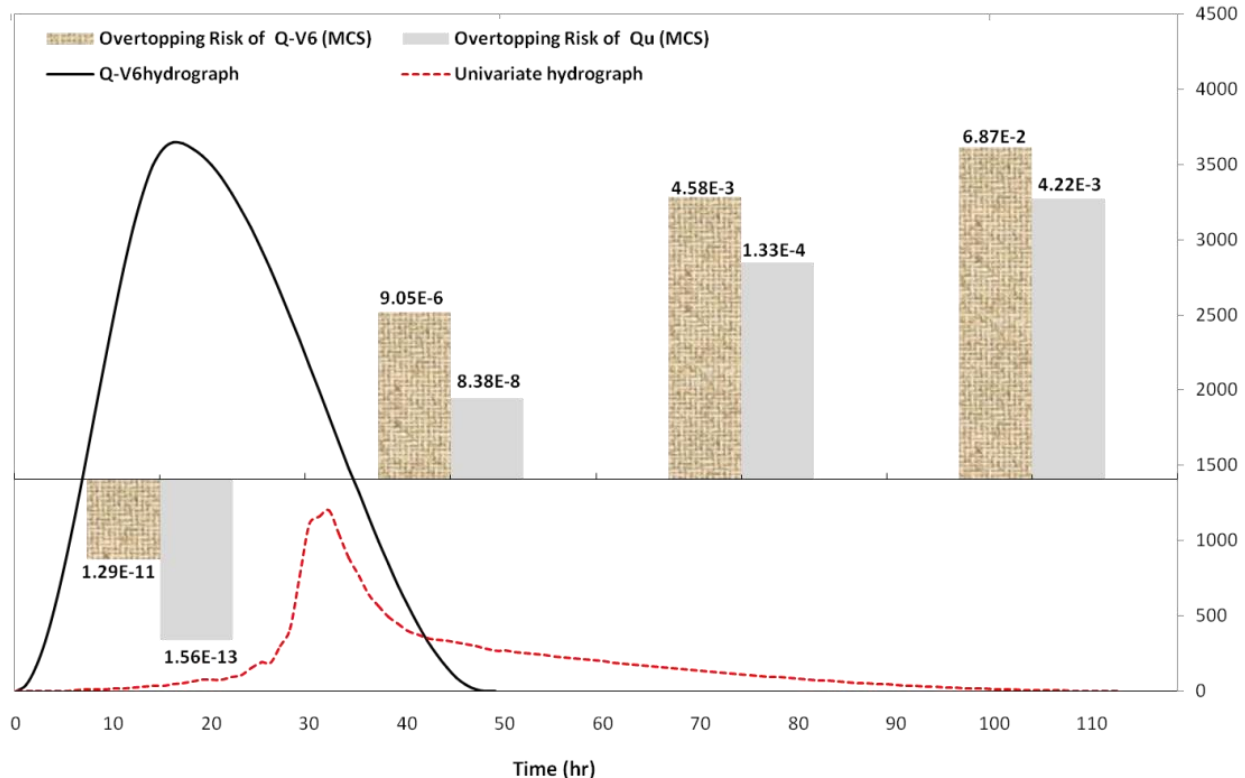

Fig. 11. Overtopping risk of $Q_{\mathrm{u}}$ and $Q-V 6$ based on MCS method.

\section{E. Goodarzi et al.}

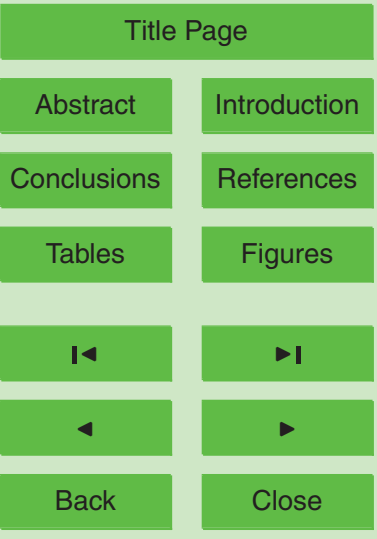

Full Screen / Esc

Printer-friendly Version

Interactive Discussion 


\section{HESSD}

8, 9757-9796, 2011

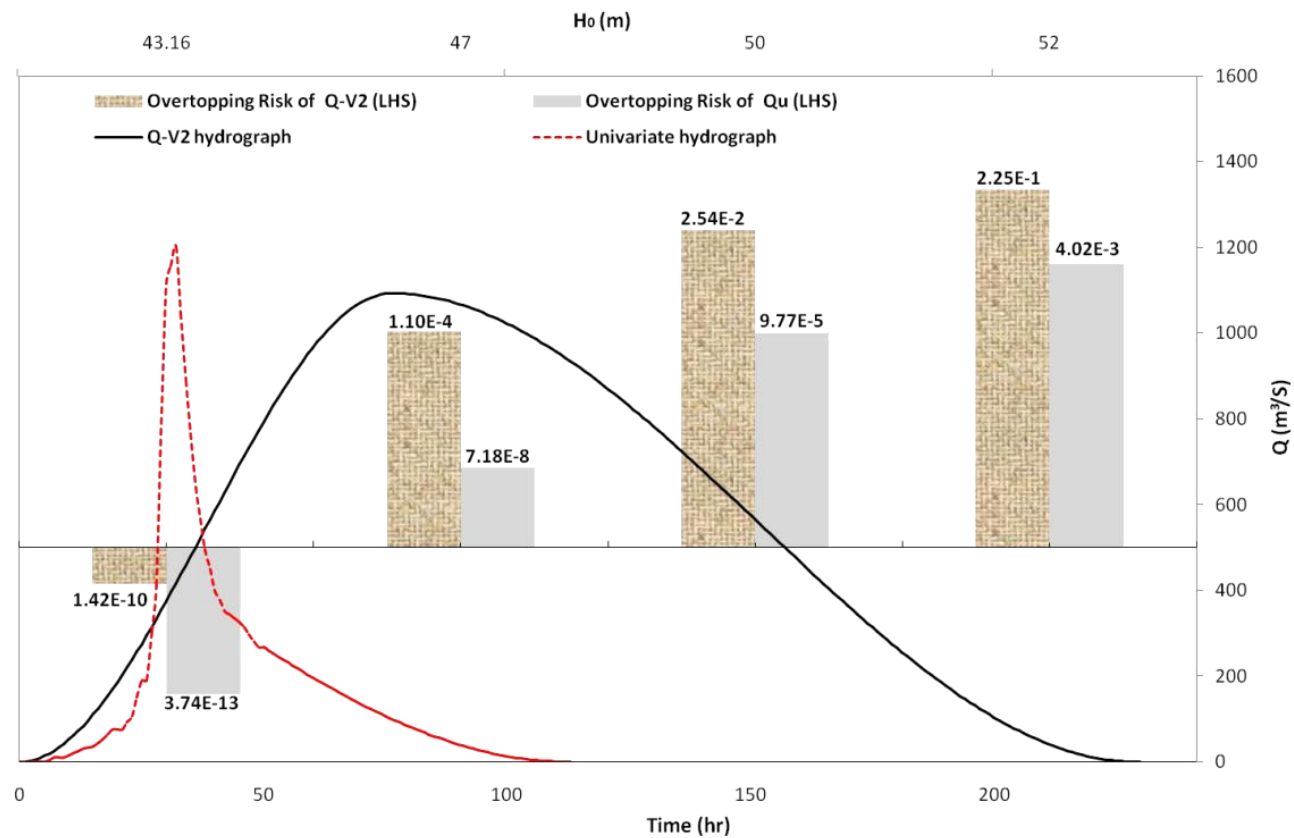

\section{Evaluation dam overtopping risk}

E. Goodarzi et al.

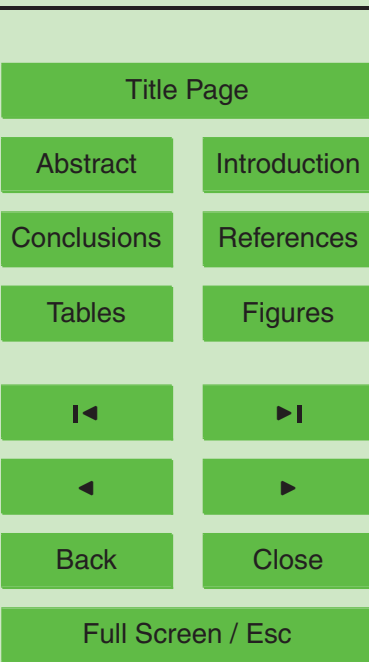

Fig. 12. Overtopping risk of $Q_{\mathrm{u}}$ and $Q-V 2$ based on LHS method.

Printer-friendly Version

Interactive Discussion

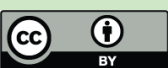




\section{HESSD}

8, 9757-9796, 2011

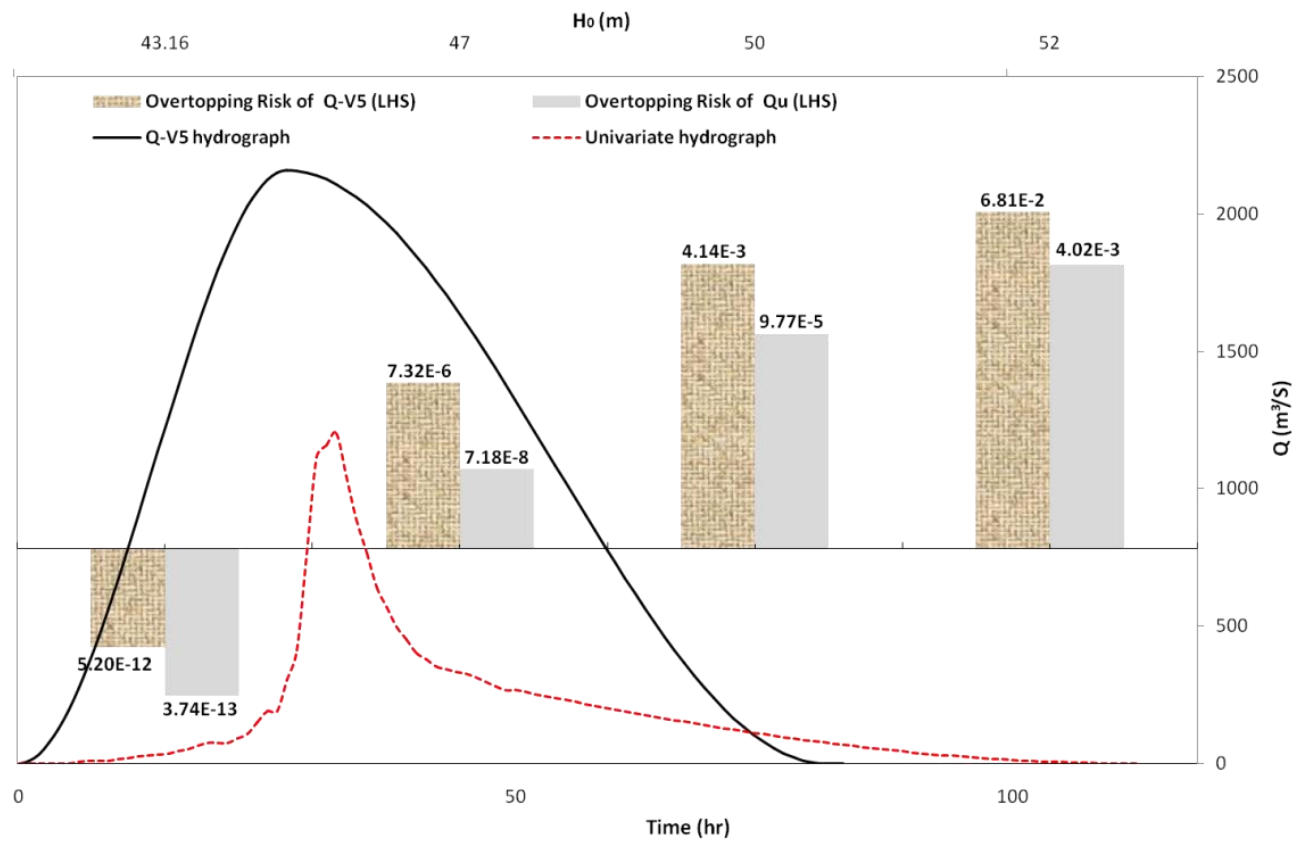

Fig. 13. Overtopping risk of $Q_{\mathrm{u}}$ and $Q-V 5$ based on LHS method.

\section{Evaluation dam overtopping risk \\ E. Goodarzi et al.}

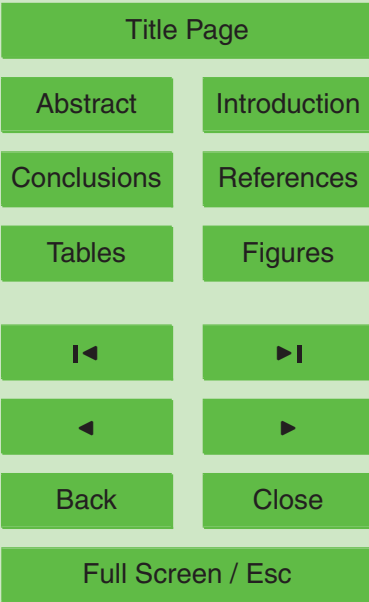

Printer-friendly Version

Interactive Discussion

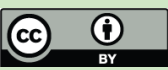

